\title{
Assent Is Not an Element of Contract Formation
}

\author{
By Val Ricks*
}

\section{INTRODUCTION: ASSENT AND CONSIDERATION}

Judges usually include assent in their lists of the elements of contract formation. ${ }^{1}$ After all, the Restatement (Second) of Contracts appears to

\footnotetext{
* Professor of Law, South Texas College of Law, Houston, Texas. The author wishes to thank participants at the 7th Annual International Conference on Contracts, at Thomas Jefferson School of Law, San Diego, March 2012; the Spring Conference on Contracts, February 2010, at University of Nevada, Las Vegas William S. Boyd School of Law; and the J. Reuben Clark Law Society Faculty Section Conference, January 2011, at Golden Gate University School of Law, San Francisco. The author wishes in particular to thank, for discussions of the paper's arguments, Gabriel Aitsebaomo, Dan Burk, Charles Calleros, Miriam Cherry, Okezie Chukwumerije, Robert Farrell, Mark Gergen, Victor Goldberg, Jack Graves, Richard Harris, Hila Keren, Thomas Kleven, Phillip Page, Deanna Pollard Sacks, Gordon Smith, Steve Ware, Darnell Weeden, and Debra Zalesne. The author also wishes to thank John Baker, Allan Farnsworth, David Ibbetson, Karl Llewellyn, Joe Perillo, Elizabeth Ricks, A.W. Brian Simpson, Ludwig Wittgenstein, and the approximately thirteen hundred former students in the author's Contracts I classes from 1998-2011.

1. See, e.g., CAL. CIV. CodE $\S \S 1550,1565$ (West 2011); I.C.E. Contractors, Inc. v. Martin \& Cobey Constr. Co., 58 So. 3d 723, 725 (Ala. 2010) ("[O]ne of the requisite elements of a valid contract is mutual assent to the essential terms of the contract.”); Roland v. Ford Motor Co., 655 S.E.2d 259, 263 (Ga. Ct. App. 2007); Mallory v. Detroit, 449 N.W.2d 115, 118 (Mich. Ct. App. 1989); Estate of Davis v. O’Neill, 42 So. 3d 520, 527 (Miss. 2010) (“In order for a contract to be valid, six elements must be present: . . . (5) mutual assent . . . .”); Kenney v. Vansittert, 277 S.W.3d 713, 720 (Mo. Ct. App. 2008); Cap Care Grp., Inc. v. McDonald, 561 S.E.2d 578, 582 (N.C. Ct. App. 2002); Vander Heide v. Boke Ranch, Inc., 736 N.W.2d 824, 832 (S.D. 2007); Doe v. HCA Health Servs. of Tenn., Inc., 46 S.W.3d 191, 196 (Tenn. 2001); Wellington Power Corp. v. CNA Sur. Corp., 614 S.E.2d 680, 684 (W. Va. 2005); Western Mun. Constr. of Wyo., Inc. v. Better Living, LLC, 234 P.3d 1223, 1228 (Wyo. 2010) ("The elements are the same as the elements of any contract: offer, acceptance, and consideration, and establishment of the existence of these elements leads courts to conclude that mutual assent has occurred."). This fact is considered so uncontroversial that unpublished decisions repeating the mantra within the last ten years are legion. See, e.g., Braca v. Countrywide Home Loans, Inc., No. CV 054013527S, 2008 WL 2930297, at *3 (Conn. Super. Ct. Jul. 8, 2008); Gates v. Praul, No. 10AP-784, 2011 WL 6036397, at *4 (Ohio Ct. App. Dec. 6, 2011); Educ. Res. Inst. v. Moss, No. M2005-02378-COA-R3-CV, 2006 WL 2080382, at *4 (Tenn. Ct. App. Jul. 26, 2006); see also, e.g., Szambelak v. Tsipouras, C.A. No. 936-VCN, 2007 WL 4179315, at *5 \& n.55 (Del. Ch. Nov. 19, 2007) (citing In re Estate of Justison, No. Civ. A 20054, 2005 WL 217035, at*10 (Del. Ch. Jan. 21, 2005)). Sometimes courts overdo it. In S.N. v. M.B., the court said, "Essential elements of a valid contract include an offer, an acceptance, ... . [and] a manifestation of mutual assent...." 935 N.E.2d 463, 471 (Ohio Ct. App. 2010); accord Weinberg v. Dickson-Weinberg, 220 P.3d 264, 292-93 (Haw. Ct. App. 2009), aff'd in part, vacated in part by 229 P.3d 1133 (Haw. 2010). And in In re Guardianship \& Conservatorship of Price, the court overstated, "The only required elements of a binding contract are mutual assent to the contractual terms manifested by an offer and acceptance.” 571 N.W.2d 214, 216 (Iowa Ct. App. 1997). The authority cited for this proposition, Kristerin Dev. Co. v. Granson Inv., requires
} 
say assent is an element. ${ }^{2}$ Law teachers affirm to their students that it is. ${ }^{3}$ In many casebooks, assent precedes consideration, ${ }^{4}$ as if assent stands independently (fortunately not in all the casebooks ${ }^{5}$ ). Assent has always preceded consideration in Williston ${ }^{6}$ and Corbin. ${ }^{7}$ Even careful scholars think of assent as elemental. ${ }^{8}$ And some contract law theorists are

consideration in addition to assent, 394 N.W.2d 325, 331 (Iowa 1986), but the Price judges must have believed that assent alone makes a contract. See also JoHn EDWARD MurRAY, JR., MURRAY ON CONTRACTS $\S 28$ (4th ed. 2001) ("There are six essential elements to the formation of a contract: (1) mutual assent ....”).

2. See Restatement (SECOND) OF Contracts ch. 3-4 (1981) (addressing "Formation of Contracts-Mutual Assent" and "Formation of Contracts-Consideration").

3. See, e.g., RANDY E. BARNETT, CONTRACTS: CASES AND DOCTRINE 287-394, 615-80 (4th

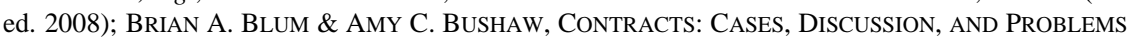
59 (2008); John D. CALAMARI ET AL., CASES AND PROBLEMS ON CONTRACTS 1-201 (5th ed. 2007); Charles L. KNapp et al., PROBlems in CONTRACt LAW: Cases and Materials 22 (6th ed. 2007); GEORGE W. KunEY \& ROBERT M. LLOYD, CONTRACTS: TRANSACTIONS AND LITIGATION $1-$ 154 (West 3d ed. 2011); JOHN EDWARD MURRAY, JR., CONTRACTS: CASES AND MATERIALS 53 (5th ed. 2001)

4. See, e.g., BARNeTt, supra note 3, at 287-394, 615-80; BLUM, supra note 3, at 59-202, 263-320; CALAMARI, supra note 3, at 1-299; KNAPP, supra note 3, at 21-214; KUNEY, supra note 3 , at 1-193; MURRAY, supra note 3, at 47-321.

5. To their great credit, some casebooks teach consideration first and introduce assent not as an element of formation but correctly (and logically) as elucidation or context for the parties' exchange. See, e.g., IAN AYRES \& RICHARD E. SPEIDEL, STUDIES IN CONTRACT LAW 28-197, 226 399 (7th ed. 2008); JoHn P. DAWSON ET AL., CONTRACTS: CASES AND COMMENT 182-353 (9th ed. 2008); E. ALLAN FARNSWORTH ET AL., CONTRACTS: CASES AND MATERIALS 29-88, 116-219 (7th ed. 2008); EDWARD J. MURPHY ET AL., STUdiES IN CONTRACT LAW 36-190, 230-459 (6th ed. 2003); ROBERT E. SCOTT \& JODY S. KRAUS, CONTRACT LAW AND THEORY 127-278 (4th ed. 2007) (introducing assent doctrine as rules that govern "the dynamics of the bargain context").

6. 1 SAMUel Williston, The LAW of Contracts (1929); see generally 1 SAMUeL WILLISTON \& RICHARD A. LORD, WILLISTON ON CONTRACTS §§ 3:4-5:21 (4th ed. 2007); 2 id. §§ 6:1-63; 3 id. §§ 7:1-51; id. § 1:3 (“An informal contract requires as one of its essentials that an agreement be present.”); id. § 2:3 (listing the supposed elements of an informal contract, including manifestation "of intent to be bound").

7. ARTHUR LinTON CORBIN, CORBIN ON CONTRACTS: ONE VOLUME EDITION 37-276 (1952) [hereinafter CORBIN ON CONTRACTS]; 1 ARTHUR LinTON CORBIN, CORBIN ON CONTRACTS Part I (Joseph M. Perillo ed., rev. ed. 1993). Murray also covers assent first and lists assent as an essential element. See MurRay, supra note 1, § 28, ch. 2-3. In fact, in Murray, consideration, promissory estoppel, and moral obligation are merely "validation devices," a label that suggests mechanical process (like a rubber stamp, or a seal, which Murray also labels a validation device) rather than a substantive requirement. See MURRAY, supra note 1, § 52(B)(1).

8. See, e.g., Danielle Kie Hart, Contract Formation and the Entrenchment of Power, 41 LoY. U. CHI. L.J. 175, 200 (2009) ("Mutual assent and consideration are still all that are needed to form a valid, traditional contract.”); Clayton P. Gillette, Rolling Contracts as an Agency Problem, 2004 WIS. L. Rev. 679, 683 (2004); Mark A. Glick, Darren Bush \& Jonathan Q. Hafen, The Law and Economics of Post-Employment Covenants: A Unified Framework, 11 GeO. MASON L. REV. 357, 397 (2002); Mark Lemley, Terms of Use, 91 MinN. L. REV. 459, 464 (2006) (“Assent by both parties to the terms of a contract has long been the fundamental principle animating contract law.”). 
anxious to show assent's primacy as the most essential or representative element. $^{9}$

With due respect to so many distinguished speakers, this is wrong. Assent is not an element of contract formation.

By element, I mean "a component or constituent of a whole or one of the parts into which a whole may be resolved by analysis." ${ }^{\prime 10}$ Resolution by analysis renders each element as particular as possible; each component or constituent is necessary to the whole. Thus, parts that can be broken down into elements are not themselves elements. Parts that are duplicative of actual elements are also not elements. A legal doctrine is a listing of a law's necessary and sufficient elements.

On this understanding, assent is not an element of contract formation. It is duplicative of another, essential part, namely consideration. Consideration exists if the evidence shows that the promise plausibly induced a return promise or performance and that the return promise or performance plausibly induced the promise. ${ }^{11}$ Actual inducement is not necessary, though if proved is of course sufficient. The court must at least think it rational that the promise was induced by the thing exchanged, and vice versa.

Consideration subsumes assent. Whoever was induced without assenting? It is not plausible to conclude that one was induced to exchange if one has not assented to that exchange. Facts that show plausible inducement always already show assent. Inducement presupposes all the assent we ever ask for in contract law. Because

9. E.g., Charles Fried, Contract as Promise 45 (1981); Stephen A. Smith, Contract THEORY (2004); Randy E. Barnett, A Consent Theory of Contract, in PERSPECTIVES ON CONTRACT LAW 213-14 (Randy E. Barnett ed., 1995) (illustrating the importance of assent by arguing that defenses to contract show lack of assent).

10. Element, DICTIONARY.COM, http://dictionary.reference.com/browse/element?s=t (last visited Dec. 22, 2012).

11. Contracts scholars may not have seen the doctrine phrased this way before. The word "plausibly" is added to the normal way of stating it. Cf., e.g., RESTATEMENT (SECOND) OF CONTRACTS $\S 71$ (1981) ("must be bargained for" and "sought by the promisor in exchange for his promise and is given by the promisee in exchange for that promise"). By the word "plausibly" I mean to include two aspects of consideration doctrine not normally emphasized in its formulation but essential to any sound understanding of the doctrine's application: (1) that "the law is concerned with the external manifestation rather than the undisclosed mental state,” id. $\S 71 \mathrm{cmt}$. b; and (2) that the law does not judge the adequacy of consideration, id. $\S 79$. Courts thus must judge inducement by something other than the mental state and other than by looking at the objective bargain. What is left? The combined effect, in application, of these two facets of consideration means that courts in practice judge consideration by determining whether it was sensible for a promisor to make the alleged exchange. Consideration becomes, in effect, a kind of low-end rational basis review of a promise, and the word "plausibly" captures that well. The meaning of the consideration test in its application (and it has no legal meaning outside of that) requires that this aspect be included in a full statement of the doctrine. 
consideration is required to form a contract and consideration is irreducible, it is an element. Because assent is duplicative of an element, and therefore unnecessary, assent is not an element.

The observation that, though it is possible to have assent without consideration, it is not possible to prove consideration without also proving assent, is just that-an observation. I have inferred it. But it is a negative statement. Its proof requires the absence of a countering example. I have not thought of one, and when I have asserted this proposition to other contracts teachers, and to my last eight hundred or so students, they have not produced one for me. Of course, that I do not find something does not mean that it does not exist, ${ }^{12}$ but I am comforted by the analytical, historical, and logical analyses contained in this Article, none of which suggests assent independent of promise and consideration is necessary to contract formation. I take heart from the simple fact that, in litigation, courts never enforce an agreement as opposed to a promise. An agreement without a promise, a commitment, is nothing in contract law, and a consideration remains necessary. Moreover, doctrinal history shows that the common law of contract formation got along without any assent analysis from 1560 to 1818 while developing nearly all of the other substantive doctrines it now contains.

I am not arguing that the assent of the parties is not important to contract law from the standpoint of policy. Speaking from policy, I am sympathetic to the theoretical account of contract law given by Benson, ${ }^{13}$ Smith, ${ }^{14}$ and Barnett ${ }^{15}$ that-very roughly-it is helpful to say that there is property in the promise that is transferred through the mechanism of contract, and that the parties' actual assent matters. ${ }^{16}$ But the doctrine of contract formation does not talk in those terms; nor does it raise assent to that grand level of abstraction. Contract doctrine is too full of sheer moral intuition and (loose) economic welfare, too concerned with objectivity and judicial efficiency, to be explained by such grand theory. And I have little hope for a grand theory of contract doctrine, or even contract formation, partly because of doctrinal conundrums such as the one I describe in this Article. If we cannot make the elements of contract formation clear, how can we hope to theorize about contract formation

12. That I am paranoid does not mean that someone is not out to get me.

13. Peter Benson, The Unity of Contract Law, in The TheORY of CONTRACT LAW: New EsSAYs 118 (Peter Benson ed., 2001).

14. SMITH, supra note 9.

15. Barnett, supra note 9 .

16. I am also sympathetic to other accounts of contract law, such as Dan Markovits, Contract and Collaboration, 113 YALE L.J. 1417 (2004). 
correctly? I hope to take a step toward greater clarity by explaining why assent is not an element of contract formation.

Though the thesis of this paper is my own, Karl Llewellyn made a similar observation and may have reached a similar conclusion. ${ }^{17}$ But the logic of doctrine was not Llewellyn's interest, as it is mine. I believe the law should be understandable, if only because it is unfair to impose force on people without a good explanation, and without clear doctrine the explanation always sounds ad hoc. And I would like to be able to present the law to students in an understandable way, if possible. ${ }^{18} \mathrm{~A}$ believable theory of contract law is also more possible if the doctrine is clear.

My thesis also receives some support from A.W.B. Simpson, who, after describing the "superimposing [of] the doctrine of offer and acceptance upon the older doctrine of consideration," added that "this seems to me to have produced rather too many doctrines chasing a limited number of problems."19 For a time, mostly in the nineteenth and early twentieth centuries, this overlap did not seem to matter much. When consideration appeared to be waning into mere formalism in the days of Holmes and the first Restatement, and the progress of society from status to contract seemed dependent on the exercise of freedom of will, the seeming inevitability of the triumph of assent overshadowed its superfluity as an independent element of contract formation. ${ }^{20}$ But with

17. See, e.g., K.N. Llewellyn, Our Case-Law of Contract: Offer and Acceptance, II, 48 YALE L.J. 779, 802-18 (1939). I was pleased to see that Llewellyn largely agreed with me (or I with him, if you like).

In the initiation of business deals the more fruitful conceptual arrangement to deal with the material makes acceptance-in-law and consideration coincide, in regard to any promise made by an offeror. Cases do not occur to me in which an initiating offeror is barred from effective revocation, in which one cannot put a finger upon some overt phenomenon which serves conveniently to satisfy both requirements.... Thus far, I am persuaded that in initiation of business deals one can safely take the problems of acceptance and of consideration as coinciding ....

Id. at 783-84. I speculate that this observation explains the omission of consideration doctrine from Article Two of the Uniform Commercial Code; formation appears to rest merely on assent. See, e.g., U.C.C. § 2-204 (2011). Every promise that is part of a sale of goods has consideration, so ensuring assent proves that the consideration requirement is met. That a consideration requirement still holds in sales of goods under Article Two is assumed, which is why section 2-209(1) was required to abolish it for modifications, id. § 2-209(1), and why section 2-205 was required to abolish it for firm offers, id. § 2-205. But consideration requires no proof in this context if assent exists, so Llewellyn, ever practical, did not bother with it in the code.

18. The incredulity of my students as to this assertion notwithstanding.

19. A.W.B. SimpSON, INNOVATION IN NinETEENTH CENTURY CONTRACT LAW, reprinted in LEGAL THEORY AND LEGAL HISTORY 171, 187 (1987).

20. See, e.g., Clarence D. Ashley, The Doctrine of Consideration, 26 HARV. L. REV. 429, 429 (1913) ("It is further true that consciously or not the law of consideration is being modified gradually, until the present technical requirement is likely to be entirely abolished.”); Arthur L. 
consideration still ensconced in its traditional position, and not having devolved into formalism, assent's subordinate role becomes obvious to anyone who wants the doctrines to fit together.

Part I of this Article examines the Restatement (Second) of Contracts both for the state of the law and for a justification for a separate assent doctrine. Finding assent described as elemental without any justification, this Article argues on the Restatement's terms that the assent doctrine is in fact just a part of the consideration analysis.

Part II then explains why the doctrine of assent is part of contract law. Section A explains the history and origins of the assent doctrines. In fact, assent doctrines arose to solve a specific problem in the consideration analysis: When did consideration arise? Or, put another way: When did the promise become binding? It became binding because consideration was given for it. In fact, as long as consideration remains necessary, it could not become binding before that time. But partly because mutual inducement is sometimes difficult to determine, consideration doctrines were shored up with analyses of the time delay between promise and consideration, or vice versa. For example, past consideration was not allowed, and doing something one had a prior legal duty to do was not consideration. To some extent, an analysis of the time when promise and consideration occurred became a surrogate for an analysis of inducement. Hardened time doctrines broke, however, when they were applied to contracts formed by post, and the time doctrines were augmented (or replaced, depending on how the precedents are read) with assent doctrines, still as part of determining when consideration came to exist.

Section B describes the role that assent doctrines now play. Essentially, the role played by assent doctrines has not changed in nearly two hundred years. Showing when consideration came to exist for a promise is still assent's function. Consideration as a doctrine plays the foundational role in contract formation law, as Section B explains. Section B also describes how numerous attempts to reduce consideration to assent failed.

In a companion paper, Consideration and the Formation Defenses, ${ }^{21}$ to be published concurrently, I outline how contract law's defenses to

Corbin, Non-binding Promises as Consideration, 26 Colum. L. REv. 550, 556 (1926) ("It has been urged by a few that the time has come to abandon the requirement of a consideration ...."); see generally Kevin M. Teeven, The Advent of Recovery on Market Transactions in the Absence of a Bargain, 39 AM. Bus. L.J. 289, 292-334 (2002).

21. Val D. Ricks, Consideration and the Formation Defenses 62 U. KAN. L. REv. (forthcoming 
formation developed historically and fit consistently with this account. Defenses to formation-duress, fraud or misrepresentation, mistake, and unconscionability-developed prior to the existence of assent doctrines in our contract law. Moreover, they are most rationally justified as defenses not because they undercut assent but because they undermine consideration.

Part III briefly concludes: The separateness of assent should be abolished; assent should be banned from the lists. When it is banned, contract formation doctrine changes shape. I explain in Part III what courts should say instead of the standard list. In the proper formulation, emphasis is given primarily (i) to the action of the promisor that shows commitment to a definable promise, and (ii) to consideration. Assent is subsumed within the consideration analysis, and basically describes the moment consideration comes to exist when that is at issue. Assent doctrines do no more than this.

Because assent is part of the consideration element, one cannot understand assent without a prior study of consideration. Consideration therefore ought to be taught to students first, and assent's subsidiary role ought to be explained when the assent doctrines are studied. Moreover, attempts to reduce the ground of contracts to assent usually misconstrue the doctrine of consideration. ${ }^{22}$ Further theoretical projects that treat assent as if it stands alone can never address the doctrine (and the case law) squarely until they account for this disjunction. Contract was always grounded on assent, but only on assent that is already part of an exchange. There never has been a separate requirement.

\section{THE LOGIC OF THE DOCTRINE: THE RESTATEMENT (SECOND) OF CONTRACTS}

The Restatement (Second) of Contracts ${ }^{23}$ purports to make assent an element of contract formation. The Restatement drafters clearly

2013).

22. See infra Part II.B.

23. Restatement (SeCOND) of Contracts (1981). I am somewhat loathe to use the Restatement; it is a scholars' summary-and in some cases, a recommendation - rather than a treatise. Most of the rules from it that I will cite are an accurate summary of the case law, however, and most have been used by the courts. But the Restatement (Second) also represents a common way to state and understand our contract law. I take it here as a widely representative sample of the way contract formation is understood. Please keep in mind, too, that the United States has fifty jurisdictions. Focusing on the law of an individual state would decrease the relevance of my criticism, and focusing on the law of all states would in effect create an artificial moving target, as no state's law is completely guilty in all of its case law of the view rejected here. 
considered whether it was such and included language addressing the issue. That language formally separates promise, agreement, and consideration and purports to require each. But the Restatement gives no real reason for doing so. The added conceptual baggage is very confusing and appears to serve no purpose relevant to contract law. Moreover, the Restatement in large part undercuts its own position on the issue by limiting assent conceptually so that it mimics the consideration requirement.

\section{A. The Position}

When it comes time to describe assent, the Restatement (Second) has a whole chapter devoted to the subject: "Chapter 3: Formation of Contracts-Mutual Assent." ${ }^{24}$ This chapter is separate from the subsequent chapter devoted to consideration: "Chapter 4: Formation of Contracts-Consideration." 25 Placing the two topics in separate chapters, with assent first, suggests that the two are separate and independent elements. Moreover, the primary statement of elements for formation appears in chapter 3, section 17: "[T] he formation of a contract requires a bargain in which there is a manifestation of mutual assent to the exchange and a consideration." 26 The sentence formally separates assent- "manifestation of mutual assent to an exchange" - on the one hand, and consideration on the other.

This formal statement appears to make assent separately necessary. The full conceptual structure of the Restatement on this issue is subtly stated, however, primarily by definition. "Contract" is a promise "for the breach of which the law gives a remedy...."27 "Bargain" is "an agreement to exchange promises or to exchange a promise for a performance or to exchange performances." 28 "Consideration," on the other hand, is in the Restatement's terms the promise or performance that is bargained for: "To constitute consideration, a performance or a return promise must be bargained for." ${ }^{29}$ And it is bargained for if it is "sought... in exchange ... and ... given ... in exchange."30 So, technically, the consideration is the thing agreed to that, being agreed to,

\footnotetext{
24. Id. ch. 3 .

25. Id. ch. 4.

26. Id. § 17(1).

27. Id. § 1 .

28. Id. $\S 3$.

29. Id. § 71(1).

30. Id. § 71(2).
} 
makes an agreement a "bargain." What the Restatement requires is an agreement to an exchange of promise and consideration. Put another way, a bargain is an agreement that involves an exchange, and a consideration- $\mathrm{a}$ promise or performance that is exchanged for a promise - is the kind of exchange that is required. That is supposed to be the distinction, and it technically splits assent off from consideration.

What does the assent concept add? Why does the Restatement not require merely a promise and consideration? Consideration, after all, must be "bargained for."31 Why add assent?

\section{B. Why Do This?}

The Restatement leaves us at a loss here. I could not find an explicit argument. I realize that the Restatement does not have to make an argument for what the law should be. It is supposedly only reporting the law, and enough assent language has been written in contract cases that it would have been hard for the Restatement authors to deny that assent is part of the law. And enough courts consider it to be separate that there is plenty of precedent for saying it is so. But I cannot help but think as I read through the Restatement that, if chapters 4 and 3 had been switched, by the time the Restatement authors worked through the consideration chapter they would have wondered why they needed an additional element.

Analytically, the assent requirement just does not add anything. Is it possible for a promise to have consideration and not already be the subject of an agreement as the Restatement defines it? I do not think so. Here, the Restatement's reliance on the word "bargain" to describe an agreement to an exchange is telling. Only a weird kind of logic would allow a promise and consideration to be bargained for but in the end not be a bargain. If in fact promise and consideration are "sought . . . and ... given ... in exchange for each other," 32 then the promisor and person putting up the consideration have manifested mutual assent to the exchange. The seeking and giving in exchange themselves manifest assent. So if consideration is proved, then looking in addition for a manifestation of mutual assent is pointless.

Perhaps at some point in our distant past, say, when Holmes was still alive, it was someone's goal to argue that consideration was a mere 
form. $^{33}$ And then the argument for assent would have been something like: Assent to the deal is what matters, and consideration is like the seal. If it were like a seal, then a mere pretense of consideration should be legally effective; a formal or merely nominal consideration, like putting down a dollar, should be sufficient. But the Restatement rejects the view that consideration is mere pretense. ${ }^{34}$ The Restatement requires that the external manifestations of the parties show "a reciprocal relation of motive or inducement." 35 How could the evidence show that the parties were induced by promise and consideration and not show that the parties agreed to be induced? Such a case will never happen.

Finding independence for the assent doctrine is rendered more difficult by the Restatement's limitations of the assent requirement itself. In section 17, the Restatement states that assent is necessary, but then other sections describe limitations of assent in such a way that the assent requirement looks largely like a restatement of the consideration doctrine. For instance, "Manifestation of mutual assent to an exchange requires that each party either make a promise or begin or render a performance." 36 But we already knew that; the consideration element requires it. Contract law is about promises- "a promise for the breach of which the law gives a remedy" 37 - and consideration requires the other party to either make a promise or begin or render a performance. ${ }^{38}$ Why add agreement as an element and then limit it to apply only when consideration exists?

That is not the only limitation on assent. Conduct purporting to be assent is only effective if the actor "intends to engage in the conduct and knows or has reason to know that the other party may infer from his conduct that he assents." 39 If assent were all that mattered in contract formation, the extra requirement about knowing or having reason to know what this assent would mean to the other party would not be necessary. But we also require consideration. If a promise is given for

33. See Restatement of Contracts $\S 84 \mathrm{cmt}$. b, illus. 1 (1932). Holmes, who died in 1935, argued that consideration was a formality. For the arguments of the first Restatement and Holmes, see infra Part II.B.2.c.

34. RESTATEMENT (SECOND) OF CONTRACTS § $71 \mathrm{cmt}$. b (“[A] mere pretense of bargain does not suffice, as where there is a false recital of consideration or where the purported consideration is merely nominal.").

35. Id. ("Here, as in the matter of mutual assent, the law is concerned with the external manifestation rather than the undisclosed mental state: it is enough that one party manifests an intention to induce the other's response and to be induced ....”).

36. Id. § 18.

37. Id. $\S 1$.

38. Id. § 71.

39. Id. § $19(2)$. 
consideration, then the promise and consideration are already sought for and given in exchange for each other. ${ }^{40}$ If you are the promisee, for example, how is it possible that you could seek for and give a promise or performance in exchange for a promise and not know or have reason to know that the other party might think that is what you are doing? It would hardly be "in exchange" if the other party did not know or have reason to know that it was, and if it was "in exchange," surely the other party would have reason to think you gave assent. I think it very odd to require assent separately from consideration and then impose on it a limitation that restricts it to something that will already occur if a consideration exists.

Here is another limitation: "It is essential to a bargain that each party manifest assent with reference to the manifestation of the other." ${ }^{41}$ I could not have said it better, but the Restatement (Second)'s point in stating this (in section 23 of Chapter 3: Formation-Mutual Assent ${ }^{42}$ ) is, again, to place another restriction on what will count as assent. Illustration 4 to section 23 notes, "A sends B an offer through the mail to sell A's horse for $\$ 500$. While this offer is in the mail, $B$, in ignorance thereof, mails to A an offer to pay $\$ 500$ for the horse. There is no contract." ${ }^{43}$ Well, there is no exchange, so there is no consideration. Of course there is no contract. Did we need to add a requirement of assent and then limit it so that, if consideration is also required, it could not possibly have been otherwise?

It gets worse. Section 24, which defines "offer," requires a "manifestation of willingness to enter into a bargain, so made as to justify another person in understanding that his assent to that bargain is invited and will conclude it." 44 The Restatement defines "bargain" as "an agreement to exchange," 45 but here no agreement has yet occurred. So, in the second instance of "bargain" in this definition of "offer," the Restatement uses "bargain" outside of its definition for the word. Here, in an offer, no agreement has yet occurred. In the Restatement's terminology, bargain minus agreement is merely exchange. ${ }^{46}$ So the requirement is that the offeror propose an exchange, i.e., promise and consideration.

\footnotetext{
40. See id. $\S 71 \mathrm{cmt} . \mathrm{b}$.

41. Id. § 23.

42. Chapter 3 comprises sections 17-70.

43. Id. § $23 \mathrm{cmt}$. d, illus. 4.

44. Id. $\S 24$.

45. Id. $\S 3$.

46. See id. cmt. c.
} 
Acceptance is also defined like this; acceptance "of an offer is a manifestation of assent to the terms thereof made by the offeree ...."47 The "terms thereof" are the exchange-namely, the promise and consideration. Assent always returns to consideration. (As consideration is still required, why would the law go anywhere else?) Keep in mind that offer and acceptance also require that "each party either make a promise or begin or render a performance." 48

By this point I want to throw up my hands. Why do we need an additional element if the one we make up must in the end look just like the one we already had?

We can summarize: Assent must be to an exchange; ${ }^{49}$ assent requires that each party put up either a promise or performance; ${ }^{50}$ what each party does must have reference to what the other party does; ${ }^{51}$ and assent must be given by one who knows or has reason to know that the other party may take it as a bargain. ${ }^{52}$ A promise and consideration meet all of these requirements. Moreover, a promise and consideration are always necessary. Assent that does not include promise and consideration is legally ineffective. In contract law, a promise is required. Consideration is still required. So all the assent in the world (even signing in blood ${ }^{53}$ ) will not make the promise enforceable without consideration. Assent without consideration is dead.

But showing promise and consideration always shows assent! Seeking for and giving in exchange a promise and consideration are acts that one does voluntarily; assent is implied in them. Showing a promise and a consideration (bargained for that promise) always proves a bargain as the Restatement defines it, logically as well as factually. It follows that the assent analysis is either merely a part of the consideration doctrine, or it is superfluous.

Perhaps some might say that the assent requirement, because it focuses on an objective manifestation, ensures that the law aims to protect the justifiable reliance of the other party and keeps us from getting bogged down in determining the subjective motive or inducements of contracting parties. But this argument is unrelated to

47. Id. §50.

48. Id. § 18

49. Id.

50. Id.

51. Id. § 23.

52. Id. § 19(2).

53. E.g., Kim v. Son, No. G 039818, 2009 WL 597232, at *3 (Cal. App. Dep’t Super. Ct. Mar. 9 , 2009) (a promissory note written in blood denied enforcement for lack of consideration). 
whether assent is necessary. Consideration, as well as assent, is limited to objective manifestations. The Restatement (Second) states:

In the typical bargain, the consideration and the promise bear a reciprocal relation of motive or inducement: the consideration induces the making of the promise and the promise induces the furnishing of the consideration. Here, as in the matter of mutual assent, the law is concerned with the external manifestation rather than the undisclosed mental state: it is enough that one party manifests an intention to induce the other's response and to be induced by it and that the other responds in accordance with the inducement.

In other words, concern for the other party's reasonable impressions is part of the consideration requirement as well as the assent analysis. I believe they are consistent, and must be so because they are the same requirement, namely that of a promise and consideration, objectively proved. ${ }^{55}$ Consideration and promise are what matters here.

If analysis of promise and consideration is sufficient to show an enforceable promise, why analyze assent? Why does the Restatement (Second) require a "bargain," defined as both manifestation of assent and consideration? ${ }^{56}$ The Restatement does include in its explanation of definitions a kind of justification for its bargain concept:

Bargain has a narrower meaning than agreement, since it is applicable only to a particular class of agreements. It includes agreements which are not contracts, such as transactions where one party makes a promise and the other gives something in exchange which is not consideration, or transactions where what would otherwise be a contract is invalidated by illegality. As here defined, it includes completely executed transactions, such as exchanges of goods (barters) or of services, or sales where goods have been transferred and the price paid for them, although such transactions are not within the scope of this Restatement unless a promise is made. ${ }^{57}$

This is as close as I have found to an explanation for requiring a separate assent analysis. It does not hold up very well. Bargains that are not

54. Restatement (SECOND) OF Contracts $§ 71 \mathrm{cmt}$. b.

55. Consideration analysis has always been based on objective manifestations of intent. See Joseph M. Perillo, The Origins of the Objective Theory of Contract Formation and Interpretation, 69 FORDHAM L. REV. 427, 436-38 (2000). Both assent and consideration will yield to a finding that neither party had subjective intent. If proof exists that neither party subjectively intended to assent to the deal, as in, e.g., Keller v. Holderman, 11 Mich. 248 (1863) (which, incidentally, does not specify whether its holding is based on assent or consideration), then it is not plausible that either was induced by the other's promise or performance, and no consideration exists.

56. RESTATEMENT (SECOND) OF CONTRACTS § 3.

57. Id. $\S 3 \mathrm{cmt}$. c. 
contracts only because they lack consideration ought to be handled under the consideration analysis: adding a bargain requirement adds nothing. Illegal bargains are handled under the consideration analysis as well as under a free-roaming "void for illegality" 58 or "void for public policy" analysis. The rest of the things bargain addresses are by the Restatement's own admission outside the scope of contract law. There simply is precious little to justify a separate chapter 3 .

Fortunately, we can look back at the historical record and figure out how this happened. When we do, we find that assent analysis serves a real and valuable purpose, not as a separate element of contract formation but as a mechanism for determining when the real test for enforceability was met-for determining when there was consideration. To this history we now turn.

\section{THE PRECEDENTS SHOW A ROLE FOR ASSENT ANALYSIS: DETERMINING WHEN CONSIDERATION EXISTS}

\section{A. The Story of Assent: Or, How Assent Became Part of the Consideration Doctrine and the Law of Contracts}

Just a relatively brief two hundred years ago, the common law of contract had no doctrine of assent. The story of how assent entered the law of contracts establishes assent's position as an adjunct to the analysis of consideration. ${ }^{60}$

In the 1790 United Kingdom case of Cooke v. Oxley, ${ }^{61}$ a seller and a shopper for commodities had a conversation about 266 barrels of tobacco. $^{62}$ The seller proposed to sell them to the shopper at a certain price. $^{63}$ The shopper wanted until four o'clock PM to think about it. ${ }^{64}$ The seller agreed to give him until four o'clock. ${ }^{65}$ Sometime that afternoon, before four o'clock, the shopper decided to buy at that price and gave the seller notice. ${ }^{66}$ The seller never delivered. ${ }^{67}$

\footnotetext{
58. See, e.g., In re OCA, Inc., 552 F.3d 413, 423 (5th Cir. 2008).

59. See, e.g., Sternaman v. Metro Life Ins. Co., 170 N.Y. 13, 19 (N.Y. 1902).

60. I am indebted to A.W.B. Simpson for the importance of Adams v. Lindsell, (1818) 106 Eng. Rep. 250 (K.B.), 1 B. \& Ald. 681, in this story. See SimPSON, supra note 19, at 182-86.

61. (1790) 100 Eng. Rep. 785 (K.B.), 3 T.R. 653.

62. Id. at $785-86$.

63. Id. at 786 .

64. Id.

65. Id.

66. Id.

67. Id.
} 
The question in the case was perhaps not what you would expect. If these facts were to arise today, we might ask whether the seller made an offer and whether the power to accept survived the conversation and lasted until the time of acceptance. ${ }^{68}$ The seller never retracted the offer. ${ }^{69}$ One might expect that a contract formed.

The shopper won at trial, but the seller appealed on the ground that "there was no consideration for the [seller's] promise.,"70 In fact, on appeal that was the only question. There was no talk of assent, offer, or acceptance. $^{71}$ Only consideration was at issue. The judges-Kenyon, Buller, and Grose-thought that no consideration existed. ${ }^{72}$ Moreover, they wasted no time with the case. Kenyon stopped argument even before seller's counsel spoke. ${ }^{73}$

The reasoning is curious to us now, perhaps. Kenyon declared, "Nothing can be clearer than that at the time of entering into this contract the engagement was all on one side; the other party was not bound ...."74 The seller's promise "was therefore nudum pactum."75 To restate, when the seller promised, the shopper promised nothing. The seller's promise was therefore without consideration. Kenyon's colleagues agreed. Per Buller,

In order to sustain a promise, there must be either a damage to the plaintiff, or an advantage to the defendant: but here was neither when the contract was first made. Then as to the subsequent time, the promise can only be supported on the ground of a new contract made at four o'clock; but there is no pretence for that. ${ }^{76}$

And Grose: "The agreement was not binding on the plaintiff before four o'clock; and it is not stated that the parties came to any subsequent agreement; there is therefore no consideration for the promise."77

68. See Keller v. Bones, 615 N.W.2d 883, 888 (Neb. 2000); see, e.g., Senior Settlements, LLC v. Growth Trust Fund, 373 F. App’x 287, 291-92 (3d Cir. 2010); Neff v. World Publ'g Co., 349 F.2d 235, 245 (8th Cir. 1965); Starlite Ltd. P'ship v. Landry’s Rests., Inc., 780 N.W.2d 396, 400 (Minn. Ct. App. 2010); Akers v. J.B. Sedberry, Inc., 286 S.W.2d 617, 620-23 (Tenn. Ct. App. 1956); RESTATEMENT (SECOND) OF CONTRACTS § 41 (1981).

69. Cooke, 100 Eng. Rep. at 786.

70. Id.

71. Id.

72. Id.

73. Id.

74. Id.

75. Id.

76. Id.

77. Id. 
To us, this rationale may make no factual sense. Of course the shopper did not promise at the time the seller promised: The seller gave the shopper until four o'clock PM, so no one expected the shopper to promise earlier! And, we would say, the shopper returned a promise before the seller withdrew the offer ${ }^{78}$ so a contract should have formed. But Kenyon did not think this way. That the promises came at different times was a deal killer. $^{79}$

Kenyon also could not have been looking for assent plus some sort of bargain form. Objective assent, particularly from the shopper's perspective, occurred. ${ }^{80}$ And, in fact, there was no evidence in the case of the seller's lack of subjective assent. ${ }^{81}$ If consideration is, as Holmes declared just eighty years later (after canvassing law from the 1400s forward), "a form as much as a seal," A sale of tobacco has the form of a bargain: tobacco for money, money for tobacco. If, as Holmes said, "[a] consideration may be given and accepted, in fact, solely for the purpose of making a promise binding," then it should not have been a problem in Cooke. Whatever "convention" 84 must occur surely happened. Assent is the problem, not consideration.

But the judges' thinking can be clearly explained. First, I would point out that Kenyon, Grose, and Buller did not have available to them a doctrine of assent. The first use in common contract law of a legal concept of assent, not yet part of any doctrine, had occurred only the year

\section{Id.}

79. Id. Contrast the facts of Cooke with two cases reported by William Sheppard in 1663, on which the seller would have won:

If I offer money for a thing in a Market of Fair, and the seller agree to take my offer, and whiles I am telling the money as fast as I can, he doth sell the thing to another; and where upon such an offer and agreement that he shall keep the thing till I can go home to my house to fetch the money; in both these cases, especially in the first case, the bargains are perfect, so as the seller may not sell the thing to another, and upon the payment, or tender of the money by me, and his refusal there, I may take the thing bought, or if he refuse to let me have it, I may sue for it.

William SHEPPARD, ACTIONS UPON THE CASE FOR DEEDS, VIZ. CONTRACTS, AsSUMPSITS,

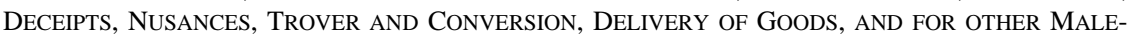
FEASANCE AND MIS-FEASANCE 74 (1675). While Sheppard talks in terms of offer and agreement here, his name for a binding contract is a "perfect bargain." Id.

80. See, e.g., Luebbert v. Simmons, 98 S.W.3d 72, 77-78 (Mo. Ct. App. 2003); Lucy v. Zehmer, 84 S.E.2d 516, 522 (Va. 1954); RESTATEMENT (SECOND) OF CONTRACTS §§ 2(1), 20, 21 (1981).

81. Cooke, 100 Eng. Rep. at 785-86.

82. Oliver Wendell Holmes, The Common LAw 215 (Mark DeWolfe Howe ed., 1963).

83. Id. at 230.

84. Id. ("Conversely, the promise must be made and accepted as the conventional motive or inducement for furnishing the consideration.”). 
before, in Payne v. Cave, ${ }^{85}$ the auction case. Payne v. Cave is the first published case (that I have found) dealing explicitly with the factual problem of a time lag between mutual promises.

Time and consideration have always been bound together, partly because consideration has always required mutual inducement, ${ }^{86}$ and inducement (causation, actually) is difficult to prove. ${ }^{87}$ A ruling against past consideration has been part of the common law since $1568 .^{88}$ The preexisting duty rule has existed since at least $1590 .^{89}$ These rules required that the promise induce the consideration. The pleading form for assumpsit of that era required that the plaintiff allege that the defendant "in consideration of X, undertook Y." Thus, the consideration had also to induce the promise. From the beginning, therefore, consideration required mutual inducement. And it was described by commentators of the time in that way: "cause arising newly on each part." "[O]ur law requireth in all contractes a mutuall consideration,

85. (1789) 100 Eng. Rep. 502 (K.B.), 3 T.R. 148.

86. See David J. Ibbetson, Consideration and the Theory of Contract in Sixteenth Century Common Law, in TOWARDS A General LaW OF CONTRACT 443-44 (Duncker \& Homblot, John Barton, eds., 1990); Val D. Ricks, The Sophisticated Doctrine of Consideration, 9 GEO. MASON L. REV. 99, 104-12 (2000).

87. One can easily overanalyze mutual inducement and time: "Now insofar as each is both cause and effect of the other, the relation between them necessarily abstracts from the temporal sequence; otherwise, each, as both cause and effect of the other, would have to be at once before and after the other, which is impossible.” Benson, supra note 13, at 173. Benson reads too much temporal linearity into the inducement doctrine. Either consideration or promise almost always happens first, and the other second, and this has never been an impediment because those applying the doctrine either have direct evidence or can safely infer that the second was given to secure the first.

88. Hunt v. Bate, (1568) 73 Eng. Rep. 605, 605 (K.B.), 3 Dyer 272a. This rule was clearly established. See Ricks, supra note 86, at 105.

89. See Greenleaf v. Barker, (1590) 78 Eng. Rep. 449 (K.B.), Cro. Eliz. 193, 74 Eng. Rep. 217, 1 Leon. 238; see also Dixon v. Adams, (1596) 78 Eng. Rep. 785 (K.B.), Cro. Eliz. 538, 72 Eng. Rep. 856, Moore 710, 74 Eng. Rep. 1006, Noy 36, 75 Eng. Rep. 1062, Goulds. 157 (reports of Dixon are confusing, but no report expresses disagreement with the principle for which it is cited here); Reynolds v. Pinhowe, (1594) 78 Eng. Rep. 669 (K.B.), Cro. Eliz. 429 (objection of counsel for the defendant), 72 Eng. Rep. 663, Moore 412.

90. Sharington v. Strotton, (1565) 75 Eng. Rep. 454, 460 (K.B.), 1 Plowden 298, 302 (Fletewood and Wray, counsel for plaintiff); JoHN H. BAKER, THE LEGAL PROFESSION AND THE COMMON LAW 369-74 (1986); Ibbetson, supra note 86, at 84; see also, e.g., 1 John H. Baker, Introduction, in Reports from the Lost Notebooks of Sir James Dyer, 109 SELDEN SoC. Xxx n.82 ("A consideration is causa meritoria for which he granted, and it may be called very well causa reciproca, sc. un mutuall cause.” (citing Lord Gerard’s Case, (1581), LI MS. Misc. 361, fo. 22r (internal quotation marks omitted))). Dyer expressed a similar thought in Calthorpe's Case, (1574) 73 Eng. Rep. 756, 759 (K.B.), 3 Dyer 334b, 336b ("A consideration is a cause or meritorious occasion, requiring a mutual recompense, in fact or in law. Contracts and bargains have a quid pro quo.”). In Sidenham v. Worlington, (1585) 74 Eng. Rep. 497, 498 (C.P.), 2 Leon. 224, 225, Justice Periam called consideration a "moving cause ... for which cause or consideration the promise was made." See also Sydenham \& Worlington’s Case, (1585) 78 Eng. Rep. 20, 20 (C.P.), Godbolt 31, 31-32 
and one part of the contract challengeth and begetteth the other." ${ }^{\text {91 }}$ The time-focused rules were just a surrogate for inducement.

The application of that time-surrogate principal to the mutual promise rule - that a mutual promise would serve as consideration-has been around since the 1570 s, at least, and probably earlier. ${ }^{92}$ Time and inducement were a concern for this type of consideration from the very beginning. ${ }^{93}$ But one sees the time requirement expressed differently for mutual promises. The judges said, in Nicholas v. Raynbred (1615), "[S]uch mutual assumpsits ought to be made at the same time; for they make the consideration, and the consideration and the promise always ought to be together: otherwise it is nudum pactum. ${ }^{\text {"94 }}$ Or, restated earlier in Kirkby v. Coles (1589), "Where mutual promises are made at the same time, an assumpsit will lie." 95 Like the other time rules, this one was also a surrogate for causation; if the promises occurred together in time, the judges felt more comfortable saying that each caused or induced the other. ${ }^{96}$ The time rule assured that the substance of

(reporting Periam's speech almost identically).

91. 2 William Fulbecke, The Parallele, OR Conference of the Civill LaW, the CANON LAW, AND THE COMMON LAW OF THIS REALME OF ENGLAND 18b (Wight 1602).

92. See West \& Stowell's Case, (1577) 74 Eng. Rep. 437, 437-38 (C.P.), 2 Leon. 155; see also Ricks, supra note 86, at 109 n.40. Baker reports pleadings centered around mutual promises in the first half of the 1500s. See II John H. Baker, The Reports of Sir John Spelman, 94 SELDEN Soc. 61 (1977). A discussion of a mutual promise case in the courts appears by 1561. See Lucy v. Walwyn, (1561) (K.B.), reported in J.H. BAKER \& S.F.C. MILSOM, SOURCES OF ENGLISH LEGAL HISTORY: PRIVATE LAW TO 1750, at 485 (1986). Baker and Milsom report that the plaintiff who pleaded mutual promises won the case. See id. at 487.

93. The lawyers arguing Lucy v. Walwyn wrangled over time and causation. See BAKER \& MiLsom, supra note 92, at 486 (arguments of Nicholls and Onslow, neither of whom disagreed with the requirement, only its application).

94. Nicholas v. Raynbred, (1615) 145 Eng. Rep. 215, 216 (Ex. Ch.), Jenk. 296. An alternate report of the case has an even stronger statement. Nichols v. Raynbred, (1615) 80 Eng. Rep. 238 (Ex. Ch.), Hob. 88 ("Note here the promises must be at one instant, for else they will be both nuda pacta.").

95. Kirkby v. Coles, (1589) 78 Eng. Rep. 394, 1 Cro. Eliz. 137, 74 Eng. Rep. 171, 1 Leon. 186. Kirkby is the earliest instance I have found.

96. See Dogget v. Dowell, (1611/01) 74 Eng. Rep. 962 (K.B.), Owen 144. Here, the plaintiff lent the defendant thirty pounds on the tenth of May. Id. The plaintiff alleged that the defendant later in consideration of the loan did promise to lend the plaintiff thirty pounds for one year or transfer to him five pounds. Id. The argument on appeal was whether the plaintiff's loan to the defendant could be consideration for the defendant's promise, even though they were apart in time. Id. Plaintiff's counsel argued that "the consideration is good, for although the promise was made at another day, yet is it in pursuance thereof, so that in law it shall be accounted all at one time ...." Id. Only one judge, Warburton, agreed. Id. The others said that the lending was "absolute, and the speaking on the [other] day cannot have such reference to the first agreement." Id. And Judge Anderson amplified, "[H]ere is no cause of action, for the consideration is precedent and not mutuall ...." Id. 
inducement occurred. This "same time" rule was still in force in 1790, when Cooke was decided. ${ }^{97}$

Lest any suggest that the lawyers of the time thought consideration was all bargain form, or just as significantly, all time form, consider the following reported statements, going back from 1671 to 1530 . The lawyers were clear that assent was an animating principle:

1671: "A mutual promise is but the construction of law on a mutual agreement."

1615: "Every assumpsit is made by the mutual agreement of both parties, and through this creates a contract ..., and because of this the person who assumes cannot make a countermand, for a bargain is a bargain .....,99

1602: “[T]he mutual executory agreement of both parties imports in itself reciprocal actions upon the case ....,100

1588: A “mutual promise and agreement” is “an assumpsit in law."101

1550: "[A]n agreement concerning personal things is a mutual assent of the parties, and ought to be executed with a recompense: ... and if it is not so, then it shall [not] be called an agreement, but rather a nude communication without effect." ${ }^{\text {,102 }}$

1530: "[S]uche bargaynes and sales be called contractes $\&$ be made by assent of the partyes vppon agreement betwene theym of goodes or landes for money or for other recompence ....,"103

This last statement, from 1530, was made before there was a consideration doctrine, but I am struck by how it resembles section 17(1)

97. The rule was cited in 1806, in II William David Evans \& M. Robert J. Pothier, A TREATISE ON THE LAW OF OBLIGATIONS app. 24 (Strahan 1806).

98. Opie v. Peters, (1671) 84 Eng. Rep. 529, 530 (K.B.), 2 Keble 837 (Saunders, counsel for defendant). Another report of the same case has Chief Justice Hale arguing, "[T]hat it is laid by way of reciprocal promise will not concern much, for every agreement is a reciprocal promise...." (1671) 86 Eng. Rep. 120, 120 (K.B.), 1 Vent. 177.

99. Hurford v. Pile, (1615) HLS MS $105 \mathrm{f}$. (K.B.), reported by Ibbetson, supra note 86, at $102-03$.

100. Slade’s Case, (1602) 76 Eng. Rep. 1074, 1077 (K.B.), 4 Co. Rep. 92b, $94 b$.

101. Penson \& Higbed's Case, (1588) 74 Eng. Rep. 756 (K.B.), 4 Leon. 99 (concession of Wray, J., during argument).

102. Reniger v. Fogossa, (1550) 75 Eng. Rep. 1, 7 (Ex. Ch.), 1 Plowden 1, 5. The word "not" is in the original but not in the English translation of Plowden. See Ibbetson, supra note 86, at 104 n.96.

103. Christopher St. German, Doctor and Student, 91 SeLDEN Soc. 228 (1974) (internal punctuation omitted). 
of the Restatement (Second) of Contracts: "[T]he formation of a contract requires a bargain in which there is a manifestation of mutual assent to the exchange and a consideration.”104

In short, no one was confused about assent's necessity. ${ }^{105}$ In fact, in some cases, courts seemed to rest their consideration holding largely on the presence of assent, often by implying a promise. ${ }^{106}$ But assent was not an element of assumpsit, the form of action that came to dominate recovery on a promise. Rather, assumpsit was, Egerton argued in 1586, consideration, promise, and breach. ${ }^{107}$ So, even in the cases that seemed to rest on the substance of assent, the courts talked, in the United States as well as England, not about assent but about consideration. ${ }^{108}$ The

104. RESTATEMENT (SECOND) OF CONTRACTS § 17(1) (1981).

105. Judges continued to say such things even after an assent requirement was made explicit. E.g., Pa., Del. \& Md. Steam Navigation Co. v. Dandridge, 8 G. \& J. 248, 308, 1836 WL 1361 (Md. 1836) (equating, in theory, an agreement with a reciprocal promise).

106. See Ricks, supra note 86, at 133-38.

107. Golding's Case, (1586) 74 Eng. Rep. 367 (K.B.), 2 Leon. 71.

108. See cases discussed by Ricks, supra note 86, at 133-38. Bruce v. Pearson, 3 Johns. 534, 1808 WL 1374 (N.Y. Sup. Ct. 1808) (per curiam), comes closest. The court's own words best explain:

The order sent by the defendant to the plaintiffs was for 6 hogsheads of rum, and other articles, at a credit of six months; and the plaintiffs sent only 3 hogsheads, and omitted part of the other articles, charging those sent, at a credit of three months. This cannot amount to a contract. There is no agreement, no aggregatio mentium between the parties, as to the thing, or subject matter of the contract. The defendant wished to have the whole of the goods; a part of them might be of no use; and until he assented to receive a part instead of the whole, he cannot be said to have contracted to pay for a part; and there can be no implied assumpsit to pay, as the goods sent never came to his hands.

Bruce, 3 Johns. at 535-36. Here we have agreement and assent but not offer and acceptance. The requirement of an agreement is, of course, fully consistent with, and was in some minds a justification for, the requirement of mutual promises, as I have noted. See supra text accompanying notes 98-106. In the end, Bruce required some act given in exchange-a consideration: he had to have received the goods. Bruce, 3 Johns. at 536.

The notion that aggregatio mentium was the meaning of agreement actually comes from the argument of Pollard in Plowden's report of Reniger v. Fogossa, (1550) 75 Eng. Rep. 1 (Ex. Ch.), 1 Plowden 1:

And as it seems to me, it is warranted by the statute: and this I shall prove by the definition of the word, by the rules of the common law in the construction of statutes, and by the intent of the makers of the said statute. And first as to the definition of the word (agreement) it seems to me that aggreamentum is a word compounded of two words, viz. (b) of aggregatio and mentium, so that aggreamentum, est aggregatio mentium in re aliqua facta vel faciendá. And so by the contraction of the two words, and by the short pronunciation of them they are made one word, viz. aggreamentum, which is no other than an union, collection, copulation, and conjunction of two or more minds in any thing done or to be done.

75 Eng. Rep. at 27. His Latin means "is a meeting of the minds regarding something to do or to be done." And thus that unfortunate phrase "meeting of the minds" crept into the law of contracts. Pollard was wrong. "Agreement" is a French word that combines the verb "agree," meaning "to please," with the suffix "-ment" to form a noun meaning "the fact of agreeing." OXFORD ENGLISH 
doctrinal upshot of these cases is therefore not that mutual inducement itself is overthrown, but that assent forms a large part of the mutual inducement analysis, though only implicitly before $1818 .{ }^{109}$ Part of the

DiCTIONARY 189, 190 (James A.H. Murray et al. eds., 1933). There is some indication in sources I have seen that the French "agree" comes from Latin's "gratus." At any rate, agreement is not a meeting of the minds. Nor did common law courts in the United States prior to Adams $v$. Lindsell (1818) rest actual rulings on that term (Bruce is the only one in which the phrase appears prior to 1820, at least in any Westlaw database). Instead, courts justified their rulings in terms of the mutual promise rule, or some other requirement of consideration, as in Bruce v. Pearson. For instance, in Tuttle v. Love, 7 Johns. 470, 472, 1811 WL 1240 (N.Y. Sup. Ct. 1811) (per curiam), the defendant promised that he would "pay the amount of the judgment, but would not pay the costs of the rule," but the agent of the plaintiff insisted on both. Offer but not an acceptance, we would say. The court said, instead, "The promise, upon the terms offered, not being accepted, ceased to operate. If one party does not accede to the promise, the other party is not bound.” Id. Promise and accession were as close as the cases come to offer and acceptance before 1818. In Allen v. Roberts, $5 \mathrm{Ky}$. (2 Bibb) 18, 98, 1810 WL 657 (1810), Allen sent several letters to Roberts inquiring about the purchase of Roberts's land. Roberts wrote back, "The lands you wish to purchase, you may have for thirty pounds per hundred acres. Cash or negroes will answer me. I shall be down in your county this fall without fail.” Id. Allen alleged that his own letters plus this response from Roberts formed a contract. Id. The court disagreed. Id. at 99. While noting the importance of intention ("The intention of the parties is the essence of a contract"), the court phrased its holding in terms of consideration:

It is essential to the validity of a contract that reciprocity of obligation should exist. In this case, it does not seem to the Court that the complainant's letters had the obligation of a contract upon him. It rather appears that he was at liberty at all times to retract his proposition.

Id. Devall v. Devall, 4 S.C. Eq. (4 Des. Eq.) 79, 83 (1809), uses the words “offer” and “acceptance," not to discuss contract formation but to rebut the notion that Mrs. Devall had entered into the settlement agreement by fraud. When the court addressed the elements of formation, it discussed only reciprocity. Id. Wood v. Edwards, 19 Johns. 205, 212, 1821 WL 1606 (N.Y. Sup. Ct. 1821), which also cites Cooke, is off point; there, the issue was only whether a mutual promise occurred, not when.

109. Of course, that is not to say that lawyers, particularly by 1800 , did not sometimes talk in terms of assent. They did. See, for instance, (1) the arguments of counsel in Head \& Armory v. Providence Ins. Co., 6 U.S. 127, 134 (1804); (2) JOHN JOSEPH POWELL, ESSAY UPON THE LAW OF CONTRACTS AND AGREEMENTS (1796) (arguing that all contracts are really about assent); and (3) civil law cases from Louisiana, such as Smith v. Kemper, 4 Mart. (o.s.) 409, 412, 1816 WL 950 (La. 1816). Pothier was beginning to be cited in America, and Pothier's theory of contract is explicitly assent based. RoBert J. Pothier, A TREATISE ON THE LAW OF OBLigATIONS (1761); see Joseph M. Perillo, Robert J. Pothier's Influence on the Common Law of Contract, 11 TEX. WESLEYAN L. ReV. 267, 270 (2005) (noting Pothier's first publication in the United States in 1802 and Evans's translation's publication in 1806). But the common law resisted promulgation of new legal requirements. So, for instance, notwithstanding arguments of Adams for the plaintiff in Head \& Armory about offer and acceptance, opposing counsel asked, "[W]as there a bargain made?" 6 U.S. at 155. And though Justice Marshall in that case actually uses the words "offered" and "acceptance" and suggests that "acceptance ... would complete the contract," he indicates two paragraphs later that what he is looking for is "a contract obligatory on both parties." Id. at 166. Marshall also uses "proposition" in place of offer. Id. at 167. Marshall's opinion in fact does not talk in terms of technical requirements but does discuss whether what happened added up to a "conclusive agreement," or "absolute agreement obligatory," or "contract obligatory," or "contract," and so on. Id. at 165-67. The point is illustrated more dramatically in the opinion of Judge Lyons in Innis $v$. Roane, 8 Va. (4 Call) 379, 398 (1797), where he concludes, "[T]here could be no contract without 
substance of mutual inducement is assent. The consideration doctrine subsumed assent analysis. Assent was latent in consideration. Shall I say it another way? Being induced by something presumes assent to it. The courts had no need to inquire after assent explicitly, because they required that a broader element be proved that included assent.

This law of contracts educated Kenyon, Buller, and Grose, ${ }^{110}$ and they applied it in Cooke v. Oxley. ${ }^{111}$ They may have let the time-rule tail wag the inducement dog a bit. In Cooke, the promises were not made at the same time. The seller promised at the time the seller and shopper first spoke, and the shopper promised later in the afternoon before four o'clock PM. ${ }^{112}$ The finding of no consideration is only logical once the following premises are clear: (1) consideration requires a mutual inducement, (2) mutual inducement requires that promises be together in time, and (3) in Cooke, the promises were separated by several hours. On these three premises, no consideration existed, and the plaintiff in Cooke lost. ${ }^{113}$

Cooke is the most prominent-but not the last ${ }^{114}$ — case to follow the time rule for mutual promises. The rule was quite limiting. It did not let

mutual obligations; and there were none in this case." Then he deals with the argument using language of assent:

It was said, however, that the offer on one side and acceptance on the other, constituted the contract. But that is a mere petitio principii [question begging], which changes the words, and not the argument. For there was no acceptance in fact: nor could there be any, as the officers had not bound themselves .... and were at liberty to resign whenever they pleased.

Id. The assent-based language added nothing to the argument; the issue was consideration. William David Evans, in his appendix to the 1806 translation of Pothier, was careful to note that the common law requires consideration, and mere assent is insufficient. EVANS, supra note 97, at 19 (" $[\mathrm{T}]$ he object of law is rather to give effect to contracts founded upon the mutual exigencies of society, than to compel the execution of a voluntary engagement ....”).

110. Blackstone began lecturing on the common law while Kenyon was in training in the Middle Temple from 1750-56. Blackstone in fact preceded Kenyon in the Middle Temple by seven years, entering in 1743. In Blackstone's mind, contract was but a method of transferring a property right, which occurred if there was "an agreement upon sufficient consideration, to do or not to do a particular thing.” 3 William BlaCKSTONE, COMMENTARIES *442 (St. George Tucker ed., 1803). But agreement was merely "a mutual bargain or convention.” Id. Even agreement was thus bargain, or a reflection of consideration, similarly to the Restatement (Second)'s account. See supra Part I.A. Blackstone discusses express and implied agreements, and executory and executed agreements. 3 BLACKSTONE, supra, at 443. But offer and acceptance, and assent as a conceptual ground for contract, are absent from his discussion. See id. at 442-46. Buller entered the Inner Temple in 1765, the year Blackstone's first volume was published.

111. (1790) 100 Eng. Rep. 785 (K.B.), 3 T.R. 653.

112. Id. at 786 .

113. Id.

114. See Keep v. Goodrich, 12 Johns. 397, 400-01 (N.Y. Sup. Ct. 1815); Livingston v. Rogers, 1 Cai. 583, 586 (N.Y. Sup. Ct. 1804). Keep cites Tucker v. Woods, 12 Johns. 190 (N.Y. Sup. Ct. 
one allow time for the other party to decide, as in Cooke, or for promising at any distance. The rule must often have been a mild fiction; obviously mutual promisors did not talk over each other. ${ }^{115}$

But by the time of Cooke, change was brewing. The 1789 opinion in Payne v. Cave $e^{116}$ foretold it. Payne involved an auction sale, a transaction normally thought of as mutual promises actionable in assumpsit. ${ }^{117}$ Payne was in fact brought as an assumpsit on a mutual promise, ${ }^{118}$ but the defendant argued that mutual promises did not occur because the auction was interrupted before the hammer fell. ${ }^{119}$ The bidder bid $40 l$. for a worm tub and pewter worm. ${ }^{120}$ When the auctioneer

1815). In Tucker, Woods offered to sell his land or trade it to Tucker in October 1807. Tucker, 12 Johns. at 190. Woods stated, "This proposition shall be binding on me until the first day of January next.” Id. In December, Tucker went to Woods and announced that he was ready to trade. Id. The jury found for the defendant on the ground that Tucker had a tenant in possession and could not deliver his property. Id. On the plaintiff's appeal, the court affirmed but took notice to say that Cooke v. Oxley "is very much in point to show the contract void. In contracts, where the promise of the one party is the consideration for the promise of the other, promises must be concurrent and obligatory upon both at the same time.” Id. at 191-92. Keep also cites "Hobart 88," which is Nicholas v. Raynbred, (1615) 80 Eng. Rep. 238 (Ex. Ch.), Hob. 88 ("[T]he promises must be at one instant, for else they will be both nuda pacta.”). Livingston cites Nicholas and also Cooke. 1 Cai. at 584. An outlier citing to Cooke and purporting to follow the time rule is Utica \& Schenectady R.R. Co. v. Brinckerhoff, 21 Wend. 139, 141-42 (N.Y. Sup. Ct. 1839), unfortunately a case of unilateral contract mistakenly analyzed as a case of mutual promise.

115. This obvious point was made in the first recorded discussion of the mutual promise rule, in Lucy v. Walwyn in 1561. BAKER \& Milsom, supra note 92, at 485. Onslow argued, "There must necessarily be a distance of time between the discussion and the undertaking, for when one has spoken the other answers him afterwards: and that is 'afterwards' even if it is all in the same hour. So this is immaterial.” Id. at 487. Nicholas's hortatory language may belie the partially fictional nature of the rule: "such mutual assumpsits ought to be made at the same time; . . . the consideration and the promise always ought to be together.” Nicholas v. Raynbred, (1615) 145 Eng. Rep. 215, 216 (Ex. Ch.), Jenk. 297. Sheppard later described a requirement that the parties' "bargain" be "perfect." SHEPPARD, supra note 79, at 33-34. He gives examples:

If the Contract bee to pay part of the mony presently, and the rest at a day to come, and the seller give him time till that day to refuse; In this case the bargain is not perfect till the day, and yet if hee agree to it before the day, this may perfect it, and reciprocal Actions will lye for the things and mony. Id. at 33 .

116. (1789) 100 Eng. Rep. 502 (K.B.), 3 T.R. 148.

117. See Bartlett v. Purnell, (1836) 111 Eng. Rep. 981 (K.B.), 4 Ad. \& E 792 (allowing assumpsit for the price of goods sold at auction); Bird v. Boulter, (1833) 110 Eng. Rep. 522 (K.B.), 4 B \& Ad. 443 (allowing assumpsit by an auctioneer even though the auctioneer's assistant created the Statute of Frauds memorandum on behalf of the purchaser).

118. See Payne, 100 Eng. Rep. at 503 ("[P]laintiff ... did then and there undertake and promise to perform the conditions of the said sale....”).

119. Id.

120. Id. A worm tub and worm were a mechanism to induce distilled spirits to condense back into liquid. The tub contained cold water, and the worm was a set of pipes that ran back and forth inside the tub. Vapors went in one end of the pipes, and, if the water was cold enough, liquid came out of the other. Worm Tub, INTERWHISKEY, http://www.interwhisky.co.uk/glossary/w/worm- 
did not drop the hammer, the bidder asked, "Why do you dwell?"121 The auctioneer explained that he had been told the weight of the equipment would justify a higher price, but when the auctioneer would not warrant the weight, the bidder withdrew the $40 \mathrm{l}$. bid. ${ }^{122}$ The next day, the items were sold to the same bidder for $30 l .{ }^{123}$ The seller sued the bidder for the difference, contending that a contract formed on the first day. ${ }^{124}$

The case raises the time issue for mutual promises, but only indirectly. Presumably, an auction was generally completed quickly enough to avoid the result in Cooke v. Oxley. ${ }^{125}$ But in Payne the bidder withdrew his bid before the auctioneer's hammer fell. ${ }^{126}$ As the judges saw it, the question, therefore, was when the bidder became bound. ${ }^{127}$

This is technically a consideration question, and, in fact, consideration was the only thing left to argue about: the bidder had clearly failed to perform a promise. ${ }^{128}$ The court's guiding rationale in the case was the long-time justification for finding consideration in mutual promise cases. This rationale was always unique to mutual promises cases. In a case in which a promise is exchanged for a performance, the performance justifies both the giving of the promise and an action for the breach of the promise. Either the promisee's detriment or the benefit given in the performance to the promisor, or both, justify the suit. But a mutual promise was traditionally actionable before anyone performed, ${ }^{129}$ and the justification for this result was that the promisor in the first action might later sue the promisee on the promisee's promise. ${ }^{130}$ Said Justice Twisden in 1671: “[A]n action lies [on mutual promises] . . . because of the mutual remedy." "131 This is the same rationale cited at the end of the opinion in Payne: "But according to

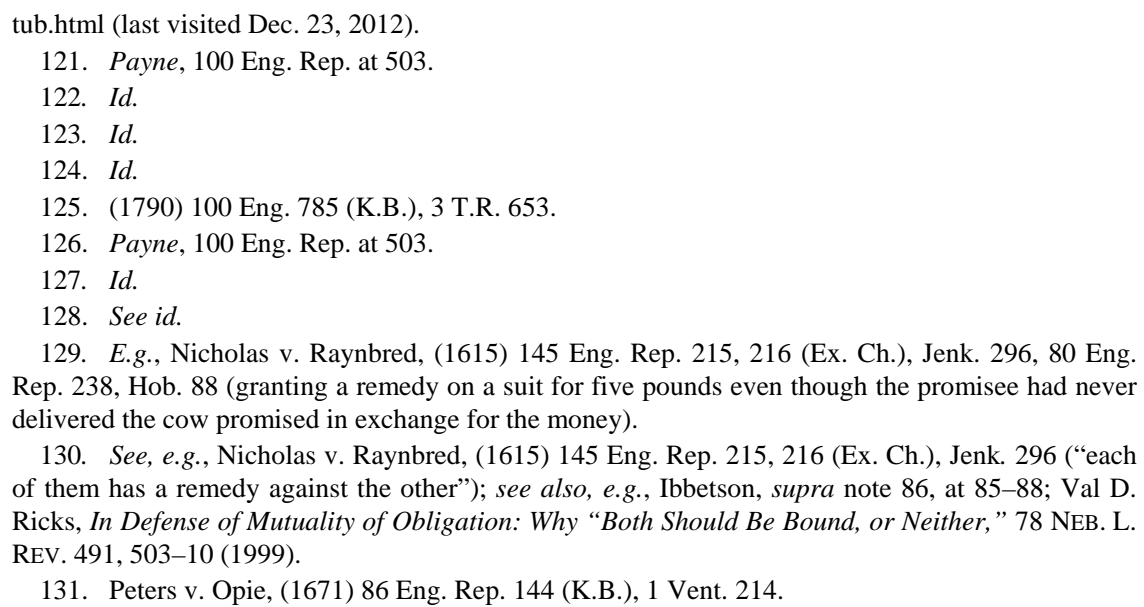


what is now contended for, one party would be bound by the offer, and the other not, which can never be allowed."132 Kenyon, who gave the opinion in Payne, knew this law well. ${ }^{133}$ Whether consideration had been given was the issue in the case.

The judges' answer was that it had not. ${ }^{134}$ When the bidder withdrew the bid, the seller had not yet promised to sell. ${ }^{135}$ Without an at least potentially actionable mutual promise, the bidder was not bound. ${ }^{136}$ This answer is consistent with the mutual promise rule, but two significant rhetorical events happened in the opinion, and both occurred because this case involved an auction that never finished. First, the court decided that the auctioneer's hammer falling signified the promise of the seller. ${ }^{137}$ This action hardly seems promissory, and the court instead called it "assent."138 Second, the court's language had to distinguish between the two promises in time. It mattered which one came first because the first promise - the bidder's, the court held-only became binding when the second, mutual promise - the auctioneer's - was made. ${ }^{139}$ Rather than talk in terms of "this promise" and "that promise," the court gave the promises names, one of which was offer:

The auctioneer is the agent of the vendor, and the assent of both parties is necessary to make the contract binding; that is signified on the part of the seller by knocking down the hammer, which was not done here till the defendant had retracted. ... Every bidding is nothing more than an offer on one side, which is not binding on either side till it is assented to. But according to what is now contended for, one party would be bound by the offer, and the other not, which can never be allowed.

And thus the court dealt for the first time in a mutual promise case with the issue of when the promisor becomes bound. ${ }^{141}$ And thus the

132. Payne, 100 Eng. Rep. at 503.

133. A year after Payne was decided, Kenyon mentioned in another decision a prominent wagering case that had denied a plaintiff relief for "no mutuality," as he phrased it, because the defendant could not have an action on a mutual promise against the plaintiff. Good v. Elliott, (1790) 100 Eng. Rep. 808, 808 (K.B.), 4 T.R. 693, 706 (discussing Blaxton v. Pye, (1766) 95 Eng. Rep. 828 (K.B.), 2 Wils. 309).

134. Payne, 100 Eng. Rep. at 503.

135. Id.

136. Id.

137. Id.

138. Id.

139. Id.

140. Id. (Kenyon, J.).

141. Before Payne, the courts did not think of promises as binding but only as actionable or not when suit was brought. In 1685, as Simpson notes, the

whole Court ... agreed [that] on a promise merely executory of both parts . . . any thing 
language of assent entered contract law. The first promise is called an offer. The second assent. But Payne is a consideration case. The question asked and answered is when consideration is given for the bidder's promise. That is when an action would become available to the bidder against the seller and thus allow the bidder to be bound.

Twenty-eight years later, Cooke and Payne became the primary sources of legal argument in a case that squarely put at issue just how much time could occur between mutual promises. ${ }^{142}$ That case pulled the words "offer," "accept," and "assent" out of Payne and gave them an explicit role in mutual promise cases. But, perhaps quite surprisingly to us now, they remained part of the consideration doctrine. The reasoning of the case is the source of constant sarcasm in Contracts class, but only because we are ignorant of its cause. The joke is on us, it turns out.

The case I am discussing is Adams $v$. Lindsell, ${ }^{143}$ of course, the mailbox rule case. This case determined that contracts could form by post. Not just minutes, as in Payne, or several hours, as in Cooke, but three days passed before the shopper replied, and seven days stretched between the letter offering to sell and the seller's receipt of a response. ${ }^{144}$ Yet a contract formed, the court held. ${ }^{145}$

Adams was riding a wave of change. ${ }^{146}$ The year before, Chancellor Eldon held an agreement formed by post specifically enforceable in

may be discharged by parol; as if I promise you 5s. if you will go to Paul's, before you go I may discharge you from the going, and thereby the other shall be discharged from paying the $5 \mathrm{~s} \ldots$. . .

A.W.B. Simpson, A History of the Common LAw of CONTRACT: The Rise of the ACtion of AssuMPSIT 469 (1975) (quoting Mayor of Scarborough v. Butler, (1685) 83 Eng. Rep. 668 (K.B.), 3 Lv. 237, 238). This is dicta in the case, but usually when the courts talked like this they had an actual past case in mind. A long line of cases allowed the promisee to discharge the promisor before the performance was due, see, e.g., Langden v. Stokes, (1634) 79 Eng. Rep. 935 (K.B.), Cro. Car. 383; SIMPSON, supra, at 470 (gathering cases), and the court in Butler was merely confirming that discharging the promisor in a mutual promise case also discharged the promisee. Butler, 83 Eng. Rep. at 668. A few earlier cases involving promises for performances had gone the other way, suggesting that the promisor could not free himself from the promise even before the other side performed. Winter v. Foweracres, (1618) 2 Rolle Rep. 19, 39; Hurford v. Pile, (1615) 79 Eng. Rep. 412 (K.B.), Cro. Jac. 483; Ward v. Grimwise, (1599) Harv. MS 105b, f. 23 (C.P.) (“Acceptance of the undertaking implies a certain contract and assumpsit on the part of the plaintiff.”). So the law was a bit muddled. Payne v. Cave took up the issue for the first time in modern terms.

142. In the meantime, these cases came up, but the courts discussed them in terms of mutual promise. See supra notes 108-09.

143. (1818) 106 Eng. Rep. 250 (K.B.), 1 B. \& Ald. 681.

144. Id. at $250-51$.

145. Id. at 251.

146. John Joseph Powell's contracts treatise of 1796 borrowed heavily in its conceptual structure from civil law, which focused on assent, while taking precedents from the common law, which did not. POWELL, supra note 109. The effect was to point common lawyers toward France for abstract 
Kennedy v. Lee. ${ }^{147}$ Though the primary issue in Kennedy was the interpretation of what the parties did, the report of Eldon's opinion does not use the word "consideration" at all. It instead talks of offer and acceptance and agreement. ${ }^{148}$ Eldon addressed the time problem nevertheless, near the end of his opinion:

I have always understood the law of the Court to be, with reference to this sort of contract, that, if a person communicates his acceptance of an offer within a reasonable time after the offer being made, and if, within a reasonable time of the acceptance being communicated, no variation has been made by either party in the terms of the offer so made and accepted, the acceptance must be taken as simultaneous with the offer, and both together as constituting such an agreement as the Court will execute. ${ }^{149}$

Eldon approved a contract formed by correspondence that occurred over seven days, with the most likely candidate letters for offer and acceptance being five days apart. ${ }^{150}$

That is a long time if, as the old case law said, "the promises must be at one instant, for else they will be both nuda pacta." ${ }^{\text {"151 }}$ But against the old rule was the social need for contracts to form by mail. If the old rule were to continue as written and practiced, Cooke would have prevented a contract in both Kennedy and Adams. What the court hit on was a compromise. Rather than repeal Cooke, then 28 years old, and Nichols ${ }^{152}$ and Kirkby, ${ }^{153}$ then 203 and 229 years old, respectively, the Adams court retained the time requirement. But if the time requirement was retained, it had to be stretched to cover mutual promises made by mail. That is what the court did-stretch the offer through time: "The defendants must be considered in law as making, during every instant of the time their letter was travelling, the same identical offer to the plaintiffs; and then the contract is completed by the acceptance of it...."154 Only then could the mutual assumpsits be made at the same time.

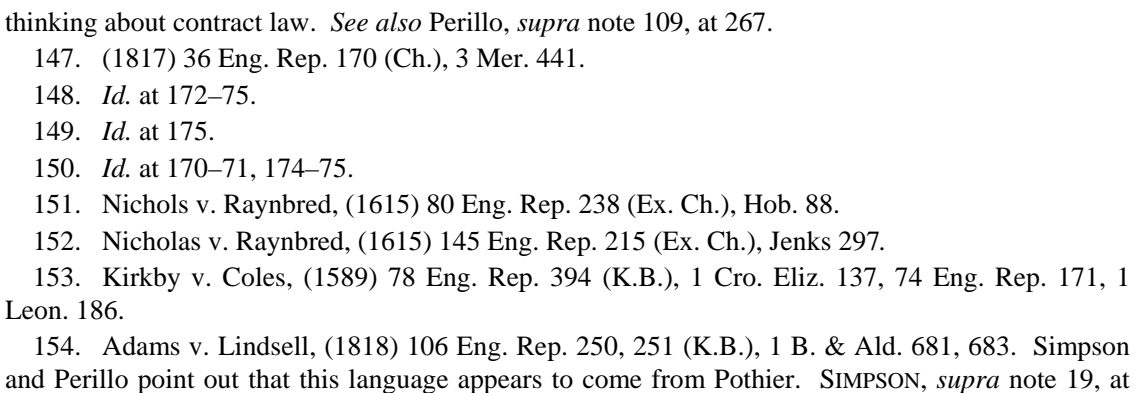


Thus, Adams, too, is a consideration case. The question was whether the second promise occurred at the same time as the first, and the court answered that it did. ${ }^{155}$ That was only relevant because the second promise was the consideration. The assent doctrine is an answer to when consideration exists, which makes the promise at issue binding. The time rule is retained-not overruled-but fictionalized. ${ }^{156}$ The time rule is now usually phrased as a requirement that acceptance occur before the power to accept terminates, and the power to accept terminates at the sooner of the time the offeror specifies, a reasonable time, the withdrawal of the offer, or the rejection of the bargain. ${ }^{157}$ That is the current formulation of the time rule for mutual promises. ${ }^{158}$

Adams widened the rhetorical leak in the dam that Payne opened. Adams was decided in June of $1818 .^{159}$ Just eight months later, in February, the U.S. Supreme Court heard, in Eliason v. Henshaw, a contract claim involving mutual promises sent by post. ${ }^{160}$ The Court rejected the claim but declined to cite Cooke or its rationale. ${ }^{161}$ In fact, the Court's narrow reasoning suggested it would follow Adams instead. In Eliason, a flour retailer sent a letter to a flour wholesaler offering to buy. ${ }^{162}$ The retailer sent the letter with the wagon that delivered flour to Harper's Ferry. ${ }^{163}$ At the bottom of the letter, the retailer wrote, "Please write by return of wagon, whether you accept our offer."164 The wholesaler did not send a reply by wagon, however. ${ }^{165}$ Instead, the wholesaler replied by post. ${ }^{166}$ Moreover, the wholesaler addressed the letter to Georgetown, not Harper's Ferry. ${ }^{167}$ The retailer declined to

\footnotetext{
185; Perillo, supra note 109, at 278 n.92.

155. Adams, 106 Eng. Rep. at 251.

156. See, e.g., Eskridge v. Glover, 5 Stew. \& P. 264, 274 (Ala. 1834) (“[B]oth parties must have assented to all the terms at the same time....").

157. See Restatement (SECOND) Of CONTRACtS §§ 35, 36 (1981).

158. Of course, these default rules of contemporary contract law are supposed to apply also to cases in which consideration is a performance, but this is an afterthought of the development. Except in a special case in section 41, all of the illustrations in this part of the Restatement involve mutual promises. Id. §§ 35-43.

159. Adams, 106 Eng. Rep. at 250.

160. 17 U.S. 225, 226 (1819).

161. Id. at 229-30.

162. Id. at 226.

163. Id.

164. Id.

165. Id. at 227.

166. Id.

167. Id.
} 
accept the delivery of flour that followed. ${ }^{168}$ Clearly, Cooke would have prohibited a contract. But the Court did not mention it. Instead, it objected that the wholesaler had replied by post-an unapproved method, and to a different place. ${ }^{169}$ But that was all. By leaping past the question whether such time-delayed consideration was possible to the question whether it occurred, the Court clearly suggested that such consideration was possible.

After that, courts jumped in. ${ }^{170}$ They began using the words "offer" and "acceptance" to evaluate contract formation. ${ }^{171}$ In 1822 the Massachusetts Supreme Court rejected Adams in an insurance case, citing Cooke, but the court's language was "offer" and "acceptance."172 The Maine Supreme Court upheld a contract by post in $1825 .^{173}$ The floodgate opened in 1830, when the New York Court for the Correction of Errors included a long discussion of offer, acceptance, Cooke, Adams, and Pothier in Mactier's Administrators v. Frith ${ }^{174}$ on the way to enforcing a contract formed through the post. ${ }^{175}$ The cases talking in these terms multiplied from there. ${ }^{176}$

168. Id.

169. Id. at 229-30 ("[I]t was entirely unimportant, whether it was sent by that, or another wagon, or in any other manner, provided it was sent to Harper's Ferry, and was not delayed beyond the time which was ordinarily employed by wagons engaged in hauling flour from the defendant's mill to Harper's Ferry.”).

170. Interestingly, not many U.S. courts cited Adams in the twelve years after it was decided. See, e.g., Thayer v. Middlesex Mut. Fire Ins. Co., 27 Mass. (10 Pick.) 326, 334 (1830) (cited by counsel); McCulloch v. Eagle Ins. Co., 18 Mass. (1 Pick.) 278, 289 n.2 (1822) (rejecting Adams on the facts of the case, which involved insurance); Mactier's Adm'rs v. Frith, 6 Wend. 103, 115-16, 119 (N.Y. 1830) (citing Adams) (counsel also argued Adams to the chancery court in this case, see 2 N.Y. Ch. Ann. 705, 1 Paige Ch. 434 (N.Y. Ch. 1829)).

171. See, e.g., Lonsdale v. Brown, 15 F. Cas. 852, 854 (C.C. Pa. 1821) (discussing whether a contract had formed based on whether an offer had been accepted); Ocean Ins. Co. v. Carrington, 3 Conn. 357, 362-63 (1820) (evaluating contract formation in terms of offer and acceptance).

172. McCulloch, 18 Mass. at 287-89.

173. Barstow v. Gray, 3 Me. 409, 415-16 (1825) ("It has been insisted in argument, that both of the parties must be bound or neither.... But it is by no means certain that the plaintiff was not equally bound.... [W] are of opinion that the defendant's letter, connected with the first letter of the plaintiff, was an offer to purchase upon certain terms; and that the second letter of the plaintiff, and the act of forwarding the wheat, was an acceptance of that offer by him; by which the contract became operative and binding on the part of the defendant, the acceptance of the plaintiff forming a sufficient consideration therefor; more especially as it appears that the defendant was advised of the manner in which his letter was understood by the plaintiff, and by his silence, as well as by his receipt of the greater part of the wheat, acquiesced in that construction.").

174. 6 Wend. 103 (N.Y. 1830). In fairness, the thinking appears to have been nearly as thorough in the intermediate appellate court. See Frith v. Lawrence, 1 Paige Ch. 434, 436 (N.Y. Ch. 1829), rev'd sub nom. Mactier's Adm'rs v. Firth, 6 Wend. 103, 158 (N.Y. 1830) (showing all the sophisticated sources were cited by Frith's lawyers).

175. Mactier's Administrators is an odd set of facts that does not arise often. Frith bought brandy from Europe for shipment to New York for resale. 6 Wend. at 104. He convinced another to 
Just what had happened took some time to sort out. Some courts of the time realized what was going on: that the vocabulary was changing, but not the substance. So Justice Collier of Alabama suggested, "Though a difference of phraseology is employed in defining the contract of sale, by the elementary writers, yet all concur in the constituents, essential to its consummation." ${ }^{177}$ Collier then concluded that, in a case of bargaining by letter delivered by an agent, though the offeree had assented mentally, no contract formed because the bargained-for performance had not occurred. ${ }^{178}$ And in Averill v. Hedge, ${ }^{179}$ an offer to sell iron wares was made through the post, and the defendant, rather than answer immediately, took two days to check the market price for iron. ${ }^{180}$ On finding the deal a good one, the defendant answered back "yes."181 The lawyers for both parties argued over whether the seller should be bound, the plaintiffs citing Mactier's ${ }^{182}$ and the court considering Cooke v. Oxley. ${ }^{183}$ The court, however, recognized that it would reach the same result under any rule, because the offer did not authorize the offeree to

join the speculation, but before the brandy arrived, Frith traveled to Jacmel in what is now Haiti. Id. From Jacmel, Frith wrote to Mactier in New York to persuade him to take the brandy speculation for his own and buy out Frith. Id. at 104-05. Mactier wrote back that he would consider the offer. Id. at 105. Then, when the brandy arrived, Mactier did receive it from the ship as owner. Id. He then wrote to Frith saying he had decided to do so. Id. at 106. Mactier enclosed a check paying Frith for Frith's interest in the venture. Id. Frith, meanwhile, at about the same time, renewed his offer to Mactier that Mactier buy out Frith's interest. Id. Before either of these last letters arrived at their destinations, Mactier died. Id. The court voted eighteen to three that Mactier was no longer a partner with Frith in the venture-in other words, that a contract formed. See id. at 111-58 (especially note Justice Marcy's opinion).

176. E.g., Falls v. Gaither, 9 Port. 605, 612-13 (Ala. 1839) (citing Adams, Mactier's, and Eliason); Eskridge v. Glover, 5 Stew. \& P. 264, 273-75 (Ala. 1834) (arguing all the consideration precedent-Payne and Cooke - before concluding that the offeror had retracted his offer); Averill v. Hedge, 12 Conn. 424, 434-36 (1838) (citing Adams, Mactier's, and Eliason); Graves v. Smedes' Adm'r, 37 Ky. (7 Dana) 344, 344 (1838); Bernard v. Torrance, 5 G. \& J. 383, 400 (Md. 1833) (“[I]t is the offer on the one side, and acceptance on the other, which constituted the contract."); Slaymaker v. Irwin, 4 Whart. 369, 380-81 (Pa. 1839); Johnston \& Lyon v. Fessler, 7 Watts 48, 50 (Pa. 1838); Neufville v. Stuart, 10 S.C. Eq. (1 Hill Eq.) 159, 166-68 (1833). Interestingly, some courts continued to cite the concurrent promise rule of Cooke. E.g., Eskridge, 5 Stew. \& P. at 275; Utica \& Schenectady R.R. Co. v. Brinckerhoff, 21 Wend. 139, 141-42 (N.Y. Sup. Ct. 1839) (unfortunately a rather clear example of unilateral contract misanalyzed as mutual promises); Johnston \& Lyon, 7 Watts at 50 (a case of no acceptance).

177. Falls, 9 Port. at 610.

178. Id. at $611-17$.

179. 12 Conn. 424 (1838).

180. Id. at 424-27.

181. Id. at $430-31$.

182. Id. at 428-30.

183. Id. at 433-34. 
speculate at the offeror's expense. ${ }^{184}$ The court then proceeded to construe Mactier's so as to allow it to reach the result demanded by Cooke: namely, by requiring an answer within a reasonable time. ${ }^{185}$ Though the vocabulary had changed to allow contracting by post, the substance of the law remained largely the same. The courts required that the offeree accept the exchange that was offered by the other party.

From the mutual promise cases, assent doctrine spread to unilateral contract cases. ${ }^{186}$ Just how the new doctrine was to apply in unilateral contract cases was not clear: is the bargained-for act required, or just assent to the offer? ${ }^{187}$ Or are they the same? The assent requirement has never fit the unilateral contract case well because one party merely acts as induced by a promise, nothing more appearing; the inducement is usually inferred or not. ${ }^{188}$ Before concluding that the act itself is the

\footnotetext{
184. Id. at 436 .

185. Id.

186. Morse v. Bellows, 7 N.H. 549 (1835). Counsel in Morse talked in terms of Cooke v. Oxley, on one side, and assent, on the other, thus pitting the rules directly against each other. Id. at 553-54. The court, in turn, talked in language of offer and acceptance. Id. at 564-65. Yet the case involved a unilateral contract, so the plaintiff's act constituted acceptance. Id. at 563. In a direct but truly
} unnecessary rejection of Cooke, the court stated,

Nor is it necessary that the consideration should exist at the time of making the promise; for if the person to whom a promise is made should incur any loss, expense or liability in consequence of the promise, and relying upon it, the promise thereupon becomes obligatory.... [O]n the performance of the condition by the promisee, it is clothed with a valid consideration, which relates back to the promise, and it then becomes obligatory. Id. at 563 .

187. E.g., Falls v. Gaither, 9 Port. 605, 613 (Ala. 1839). In Falls, one judge, Collier, insisted on the performance of the act of payment apparently demanded by the offer. Id. at 615-17. Another, Ormond, cited Mactier's for the proposition that assent was sufficient, even without the act. Id. at 621-23. Llewellyn was still arguing about this in 1939. Llewellyn, supra note 17, at 802-18. Llewellyn agreed mostly with Ormond, but then he admitted that the odd case of a real unilateral contract can exist, and offered no solution for that one except a return to the plain old bargainfocused doctrine, with assent included in it. Id. at 815 ("[S]how, in a business case, the offer communicated to the offeree, and performance of the conditions by the offeree, and any assent which may be required in law is taken for granted.").

188. Courts might infer the act induced the promise (as was generally alleged), but they might not. See Kirksey v. Kirksey, 8 Ala. 131, 133 (1845) (finding no inducement); Game \& Ux' v. Harvie, (1605) 80 Eng. Rep. 36 (K.B.), Yelv. 50 (finding inducement); Riches v. Bridges, (1602) 78 Eng. Rep. 1108 (K.B.), Cro. Eliz. 883 (finding inducement), 80 Eng. Rep. 4 (Ex. Ch.), Yelv. 4 (finding no inducement on final appeal). The court might also infer that the promise induced the act. See De Cicco v. Schweize, 17 N.E. 807, 810 (N.Y. 1917) (inferring inducement to marry from a promise made to a man for the benefit of his fiancé, though the two already planned to and did marry); Webbs Case, (1547) 74 Eng. Rep. 763 (K.B.), 4 Leon. 110 (finding inducement when a person hired another to obtain a power of attorney from a third person). Because inducement was often a matter of inference, the plaintiff might also allege that the act induced the promise and the promise induced the act when this was probably not true. That the inference was not required to be alleged allowed the court to extend the assumpsit action and the consideration doctrine to cases in which the work induced by the promise probably did not induce the promise. See, e.g., Kirksey, 8 Ala. at 133 (Ormond, J., dissenting); Brown v. Adams, 1 Stew. 51, 54 (Ala. 1827); Keyme v. 
assent the law wants, the courts had to ask (i) whether an offer of unilateral contract that was itself a promise could be accepted by a mutual promise; (ii) whether beginning the act, which signified a kind of assent, bound the promisor; and (iii) whether anything more than the act itself was required.

In the end, this exercise in assent analysis added nothing of substance to the law of formation of unilateral contracts. The bargain requirement controlled each of these questions. Performance of the bargained-for act is always acceptance of the offer of unilateral contract that is itself a promise, and any other purported acceptance has no independent legal effect. ${ }^{189}$ Further, while beginning the bargained-for

Goulston, (1664) 83 Eng. Rep. 338 (K.B.), 1 Lev. 140; Storer’s Case, (1615) 73 Eng. Rep. 605, 607, Dyer 272a, 272b; St. German, supra note 103, at 230-31 ("If he to whom the promise is made have a charge by reason of the promise, which he hath also performed, then in that case he shall have an action for that thing that was promised, though he that made the promise have no worldly profit by it. As if a man say to another 'heal such a poor man of his disease,' or 'make such a highway and I shall give thee thus much,' and if he do it I think an action lieth at the common law." (spelling and punctuation modernized)).

189. E.g., U.S. ex rel. Worthington Pump \& Mach. Corp. v. John A. Johnson Contracting Corp., 139 F.2d 274, 276-77 (3d Cir. 1943); Taylor v. Newton, 44 So. 583, 584 (Ala. 1907); Am. Oak Extract Co. v. Ryan, 15 So. 807, 809-10 (Ala. 1894); Morrell v. Quarles, 35 Ala. 544, 547 (1860); Ryer v. Stockwell, 14 Cal. 134, 137 (1859); Nathan v. Am. Photoplayer Co., 272 P. 775, 778 (Cal. Dist. Ct. App. 1928); Frue v. Houghton, 6 Colo. 318, 324-25 (1882); Oliveira v. Silva, 18 Haw. 602, 607-08 (1908); Clark v. H. Hackfeld \& Co., 16 Haw. 53, 61-63 (1904) ("In the case of unilateral contracts the performance of the act specified in the offer as the consideration makes the promise binding. Notice of acceptance is generally unnecessary.”); Perkins v. Hadsell, 50 Ill. 216, 219 (1869); Alexander Hamilton Inst. v. Jones, 234 Ill. App. 444, 446-47 (1924); Port Huron Mach. Co. v. Wohlers, 221 N.W. 843, 844 (Iowa 1928); Rawson v. Valley Ctr. State Bank, 8 P.2d 352, 353 (Kan. 1932); Brackenbury v. Hodgkin, 102 A. 106, 107 (Me. 1917); Northampton Inst. for Sav. v. Putnam, 45 N.E.2d 936, 939 (Mass. 1943); Bishop v. Eaton, 37 N.E. 665, 666 (Mass. 1894); Stensgaard v. Smith, 44 N.W. 669, 669-70 (Minn. 1890); Kolb v. Bennett Land Co., 21 So. 233, 234-35 (Miss. 1897); Underwood Typewriter Co. v. Century Realty Co., 119 S.W. 400, 404 (Mo. 1909); Roberts v. Harmount Tie \& Lumber Co., 264 S.W. 448, 448 (Mo. Ct. App. 1924); Janvrin v. Town of Exeter, 48 N.H. 83, 86 (1868); Petterson v. Pattberg, 161 N.E. 428, 429-30 (N.Y. 1928); Pierson v. Morch, 82 N.Y. 503, 504 (N.Y. 1880); In re Cowan's Estate, 13 N.Y.S.2d 374, 376-77 (N.Y. Surrogate's Ct. 1939); Winders v. Kenan, 77 S.E. 687, 689-91 (N.C. 1913); Bretz v. Union Cent. Life Ins. Co., 16 N.E.2d 272, 274 (Ohio 1938) (“Acceptance of an offer to enter into a unilateral contract can be effected only by performance of the condition prescribed and within the time fixed.”); Bradford v. Foster, 9 S.W. 195, 196-97 (Tenn. 1888); Ragosta v. Wilder, 592 A.2d 367, 370-71 (Vt. 1991); Pollock v. Brookover, 53 S.E. 795, 796 (W. Va. 1906); Weaver v. Burr, 8 S.E. 743, 747 (W. Va. 1888) (citing Eliason v. Henshaw, 17 U.S. 225, 228 (1819)); John E. De Wolf Co. v. Harvey, 154 N.W. 988, 992 (Wis. 1915); Carlill v. Carbolic Smoke Ball Co., (1893) 1 Q.B. 256 (Eng.); cf. Briggs v. Miller, 186 N.W. 163, 165 (Wis. 1922) (a fascinating case in which the offeree performed the requested act but the court held the requested act not bargained for, even though, the court stated in dicta, it might be considered acceptance of the offer). The Restatement (Second) of Contracts language supports this view. RESTATEMENT (SECOND) OF CONTRACTS § 32 cmt. b (1981) ("Language or circumstances sometimes make it clear that the offeree is not to bind himself in advance of performance.... In such cases, the offer does not invite a promissory acceptance, and a promise is ineffective as an acceptance.”); RESTATEMENT OF CONTRACTS $§ 52$ 
performance has been promoted as a kind of assent (and may give the offeree an option to finish performance), ${ }^{190}$ nothing short of full performance of the bargained-for act will require the promisor to do anything. ${ }^{191}$ This was not a substantive change in the law (granting an option to finish performance may also not have been a change). ${ }^{192}$ Finally, the courts decided that the person performing the bargained-for act must know of the offer, ${ }^{193}$ but that is latent in the consideration doctrine itself: whoever was induced by something of which they were unaware? ${ }^{194}$ Incidentally, courts also held that no notice other than

cmt. a (1932) ("In a unilateral contract the act requested and performed as consideration for the contract ordinarily indicates acceptance as well as furnishes the consideration ....”); id. § $56 \mathrm{cmt}$. a ("In the formation of a unilateral contract where the offeror is the party making the promise, as is almost invariably the case, a compliance with the request in the offer fulfills the double function of a manifestation of acceptance and of giving consideration.").

190. The Restatements handle this as a kind of option, technically but not functionally a contract until the bargained-for performance is complete. RESTATEMENT (SECOND) OF CONTRACTS $\S 45$ ("Where an offer invites an offeree to accept by rendering a performance and does not invite a promissory acceptance, an option contract is created when the offeree tenders or begins the invited performance or tenders a beginning of it."); RESTATEMENT OF CONTRACTS $\S 45$ ("If an offer for a unilateral contract is made, and part of the consideration requested in the offer is given or tendered by the offeree in response thereto, the offeror is bound by a contract ....").

191. If the offeree never finishes performance, the offeror, whose duty is conditional on the offeree's completion, never has a duty to perform. RESTATEMENT (SECOND) OF CONTRACTS § 45 cmt. e; see also supra note 190.

192. Section 45 of the Restatement (Second) of Contracts (1981) and section 45 of the Restatement of Contracts (1932) provide that, when an offeror promises in exchange for a performance, the offeree who has begun the performance has an option contract for a reasonable time in which to conclude the performance. The Restatement justifies this move on grounds of justice but also construction. RESTATEMENT (SECOND) OF CONTRACTS $§ 45 \mathrm{cmts}$. b \& d (justifiable reliance); RESTATEMENT OF CONTRACTS $\S 45 \mathrm{cmt}$. b. The first Restatement of Contracts suggested a remedy may be justified also under section 90. RESTATEMENT OF CONTRACTS $\S 45 \mathrm{cmt}$. b; see also RESTATEMENT (SECOND) OF CONTRACTS § $45 \mathrm{cmt}$. $\mathrm{f}$ (suggesting similar relief under RESTATEMENT (SECOND) OF CONTRACTS $\S 87(2)$ ). It seems obvious that a remedy for unjust enrichment also might be available. Prior case law recognized that the partly performing offeree sometimes should recover. See Hawk v. Marion Cnty., 48 Iowa 472, 477 (1878) (granting recovery through construction of the offer to a part performer of an act required for a reward); Symmes v. Frazier, 6 Mass. 344, 347 (1810) (granting recovery through construction of the offer and quantum meruit to a part performer of the performance required by a reward offer).

193. Simmons v. United States, 308 F.2d 160, 164 (4th Cir. 1962); Gale v. Town of Jamaica, 39 Vt. 610, 615 (1867); RESTATEMENT (SECOND) OF CONTRACTS $§ 51 \mathrm{cmt}$ a (requiring that offeree has knowledge of the offer).

194. In the ancient, leading case of Hunt v. Bate, (1568) 73 Eng. Rep. 605 (K.B.), 3 Dyer 227, a person "stood in" in debtor's prison for another's servant so that the servant could complete his master's work. When the master learned of this, the master promised to indemnify the stand-in if the stand-in was made to pay the servant's debt. Id. But when the stand-in had to pay, the master refused to indemnify. Id. The court said that the master was not bound because the stand-in did what he did "of his own head." Id. When the stand-in entered prison and the servant went free, the master's promise had not been made yet, and could not have induced the standing in. 
notice of performance need normally be given to the offeror; ${ }^{195}$ none ever had, in the hundreds of years in which the law had enforced these kinds of deals, so the addition of an assent requirement changed nothing there. Thus, the judicial wrangling over these issues was largely wasted effort, caused only by the misunderstanding that something in addition to or different from an exchange was required.

It is no accident that the addition of assent changed nothing for unilateral contracts. They had been enforceable without anyone explicitly considering assent for hundreds of years. The reason no one asked the assent question in all that time is that the time of formation is never at issue in a unilateral contract: no contract forms until the moment performance is complete. ${ }^{196}$ Only after folks began thinking of assent as independently necessary did they think to apply it to unilateral contracts. When the assent doctrines were applied to such contracts, they did not make sense, or had a very different sense than they did for mutual promise cases. And in the end they added nothing.

The point is that assent doctrines play the role of determining when an exchange occurs. The doctrines of offer and acceptance are aimed at saying when two parts of the consideration happened. That is the doctrines' role. Assent doctrines are the expansion of the time requirement of the mutual promise rule, applied to all contracts. Of course, if there was never a moment in time when assent was complete, then that means, indirectly, that the exchange, which subsumes assent, was never perfect, no consideration exists, and no contract formed. But the assent doctrines themselves are aimed at determining the moment in time. What we really want to know is whether an exchange occurred. The assent doctrine is thus actually part of the consideration analysis. It follows that when we think we are doing an analysis of assent in contract

195. See Am. Oak Extract Co. v. Ryan, 15 So. 807, 809-10 (Ala. 1894) (holding a contract is formed by the completion of performance); Clark v. H. Hackfeld \& Co., 16 Haw. 53, 61 (1904) (same); First Nat'l Bank v. Watkins, 28 N.E. 275, 276 (Mass. 1891) (same); Gale, 39 Vt. at 614 (same); Carlill v. Carbolic Smoke Ball Co., (1893) 1 Q.B. 256 (Eng.) (same). An exception arises if knowledge of the performance would not normally come to the offeror without some special notice, in which case the offer was construed to require notice. E.g., Bishop v. Eaton, 37 N.E. 665, 667 (Mass. 1894) (holding "where the guarantor would not know of himself from the nature of the transaction whether the offer has been accepted or not, that he is not bound without notice of the acceptance").

196. Section 45 of the Restatement modifies this rule only by adding the formation of an additional option contract at the moment the performance begins. RESTATEMENT (SECOND) OF CONTRACTS $\S 45 \mathrm{cmt}$. c ("acceptance must be complete at the latest when performance is tendered"). Formation occurs at an instant, either way. Incidentally, the Restatement also opines, in the next sentence, that beginning performance also "ordinarily furnishes consideration and creates a contract.” Id. 
law, we are actually doing an analysis of consideration. If we do not realize that is what we are doing, we are apt to do it in a confusing way.

\section{B. Assent Still Plays the Same Role Today}

\section{Logic and Doctrine}

Our doctrines now reflect this history. Even perusal of the common doctrine clearly reveals that assent retains this function-to determine when consideration exists.

For instance, an offer is, per the Restatement (Second), "the manifestation of willingness to enter into a bargain, so made as to justify another person in understanding that his assent to that bargain is invited and will conclude it." 197 This is the clearest definition, but its clarity is derived entirely from our knowledge of what a bargain is. As noted, "bargain" here does not carry the Restatement's definition. "Bargain” is defined as agreement, ${ }^{198}$ but an agreement has not yet occurred. So here "bargain" means only exchange, and the only exchange that could result in a contract forming is one that constitutes a promise and consideration. ${ }^{199}$ In other words, an offer is one half of promise and consideration, proposed to the other party.

The less functional definitions found in the case law mean this same thing. Lefkowitz's ${ }^{200}$ "clear, definite, and explicit, and leaves nothing open for negotiation"201 neither includes nor excludes enough to be definitional until one realizes what it is that is supposed to be clear, definite, and explicit. It is what the Restatement definition supplies: that we are talking about promise and consideration. ${ }^{202}$ Once one can make out a proposed exchange in the party's statement, that statement can be called an offer. That the offer contains a bargain requires that the offer contain a promise or performance offered in exchange for the promise or performance of the other party. By definition, to offer such an exchange will leave nothing further for the offeror to do, and the offeree need only assent to it. At that point, consideration will exist. This principle resolves the offer cases. ${ }^{203}$

\footnotetext{
197. RESTATEMENT (SECOND) OF CONTRACTS § 24.

198. Id. § 3.

199. Id. $\S \S 17,71$.

200. Lefkowitz v. Great Minneapolis Surplus Store, 86 N.W.2d 689 (Minn. 1957).

201. Id. at 691 .

202. RESTATEMENT (SECOND) OF CONTRACTS §§ 17, 71.

203. An advertisement normally would not qualify, as it lacks a promise; it seeks offers, not the
} 
Acceptance is likewise tied to bargain. The mirror image rule requires the offered exchange be accepted or rejected, ${ }^{204}$ and the purported acceptance of some other exchange is a new offer. ${ }^{205}$ The Restatement explains, "A qualified or conditional acceptance proposes an exchange different from that proposed by the original offeror.",206 The same is true under the Uniform Commercial Code's (UCC's) sales of goods provisions: "A contract for sale of goods may be made in any manner sufficient to show agreement," 207 and "agreement" here means "the bargain of the parties in fact."208 Llewellyn, Article Two's drafter, who recognized that assent's role overlapped with consideration's, ${ }^{209}$ included in Article Two specific language undercutting the importance of the assent doctrines: "An agreement sufficient to constitute a contract for sale may be found even though the moment of its making is undetermined." 210 And section 2-207, which when applicable dispenses with the mirror image rule, is intended to get at the parties' actual bargain in order to specify when it is complete. ${ }^{211}$ The exchange is the thing.

conclusion of a bargain. Mesaros v. United States, 845 F.2d 1576, 1581 (Fed. Cir. 1988); Brotherson v. Prof'l Basketball Club, L.L.C., 604 F. Supp. 2d 1276, 1284 (W.D. Wash. 2009) ("Advertisements, even those that state specific prices and specific instructions for communicating the intent to purchase the advertised goods, are generally not offers because they are communicated to a wide audience. Recipients of advertising are presumed to understand this, and to understand that construing an advertisement as an offer could cause 'the advertiser [to] be bound by an excessive number of contracts requiring delivery of goods far in excess of amounts available."” (citations omitted) (quoting Mesaros, 845 F.2d at 1581)); Leonard v. PepsiCo, Inc., 88 F. Supp. 2d 116 (S.D.N.Y. 1999), aff'd, 210 F.3d 88 (2d Cir. 2000). A promise made in jest would also not qualify, as its promise is untrustworthy; it seeks humor rather than a consideration. Leonard, $88 \mathrm{~F}$. Supp. 2d at 127-30; Keller v. Holderman, 11 Mich. 248, 249 (1863).

204. E.g., Foster v. Ohio State Univ., 534 N.E.2d 1220, 1222 (Ohio Ct. App. 1987) ("When an acceptance to a contract for employment does not meet and correspond with the offer in every respect, no contract is usually formed.”); RESTATEMENT (SECOND) OF CONTRACTS § 58. The Restatement explains, "This rule applies to the substance of the bargain the basic principle that the offeror is the master of his offer." Id. cmt. a.

205. See Foster, 534 N.E.2d at 1222 ("A reply to an offer which purports to accept but is conditional on the offeror's assent to terms additional to or different from those offered is not an acceptance but is a counteroffer.”); RESTATEMENT (SECOND) OF CONTRACTS § 59 (same).

206. RESTATEMENT (SECOND) OF CONTRACTS $\S 59 \mathrm{cmt}$. a.

207. U.C.C. § 2-204(1) (2011).

208. Id. § 1-201(b)(3).

209. See Llewellyn, supra note 17, at 783 ("In the initiation of business deals the more fruitful conceptual arrangement to deal with the material makes acceptance-in-law and consideration coincide, in regard to any promise made by an offeror.”).

210. U.C.C. § 2-204(2).

211. Id. § $2-207 \mathrm{cmt} .2$ ("Under this Article a proposed deal which in commercial understanding has in fact been closed is recognized as a contract."); see also id. cmt. 3 (making the efficacy of an additional or different term dependent on whether it alters "the original bargain”). In comment 6, the 
Finally, numerous cases occur in which an offer and acceptance are difficult if not impossible to find, and certainly finding them is unnecessary. ${ }^{212}$ Complex real estate and finance transactions frequently require assent from multiple parties before a contract forms. In such transactions, nothing like offer and acceptance occurs, and final documents are often signed by multiple parties and multiple representatives of each of multiple parties over a period of time while documents remain in the hands of a nonparty. Agreements involving multiple parties present no clear picture of offer and acceptance, whether the parties negotiate through an intermediary or conduct (often complex) negotiations directly. ${ }^{213}$

The traditional assent analysis also does not fit cases in which consideration is easier to imply than assent. For instance, assent in the traditional sense does not supply the moment of formation in a battle of the forms under Article Two. ${ }^{214}$ Nor is it applied straightforwardly to socalled "rolling contracts," in which terms are shipped to customers with technology products post-purchase. ${ }^{215}$ And certain cases involving employment handbooks also depart from assent analysis. ${ }^{216}$ In none of these kinds of transactions does assent analysis function well. Yet in

focus is on what the parties "agreed to," or their "agreement.” Id. cmt. 6. In the UCC, agreement is the parties' "bargain ... . in fact." Id. § 1-201(b)(3).

212. See Parviz Owsia, The Notion and Function of Offer and Acceptance Under French and English Law, 66 Tul. L. Rev. 871, 893-913 (1992); Shawn J. Bayern, Offer and Acceptance in Modern Contract Law: A Needless Concept (FSU Coll. of Law, Public Law Research Paper No. 625, 2013), available at http://ssrn.com/abstract $=2222394$.

213. See Owsia, supra note 212, at 894-99 (citing several cases and examples).

214. U.C.C. § 2-207.

215. See, e.g., Hill v. Gateway 2000, Inc., 105 F.3d 1147, 1150 (7th Cir. 1997) (holding plaintiff accepted Gateway's offer of computer by keeping computer more than thirty days where terms of offer were sent in computer's packaging and required return within thirty days if customer was unsatisfied); Stenzel v. Dell, Inc., 870 A.2d 133, 140 (Me. 2005) ("By accepting delivery of the computers, and then failing to exercise their right to return the computers as provided by the agreement, Stenzel and Gerber expressly manifested their assent to be bound by the agreement....”); DeFontes v. Dell, Inc., 984 A.2d 1061, 1071 (R.I. 2009) (“[F]ormation occurs when the consumer accepts the full terms after receiving a reasonable opportunity to refuse them.”). Some courts have called this a "layered contracting" theory of formation, so called because while "some contracts are formed and their terms fully defined at a single point in time, many transactions involve a rolling or layered process.” M.A. Mortenson Co. v. Timberline Software Corp., 998 P.2d 305, 313 n.10 (Wash. 2000) (en banc); see also, e.g., Robert A. Hillman, Rolling Contracts, 71 FORDHAM L. REV. 743, 744-45 (2002) (“Although courts and commentators focus on the time of contract formation, this analysis actually yields little fruit.... Let's go back to Llewellyn's view that people fail to read their form contracts and that bargained-for terms and conscionable terms should constitute the contract. This approach should be employed ....”).

216. See Toussaint v. Blue Cross \& Blue Shield of Mich., 292 N.W.2d 880, 885 (Mich. 1980) ("[S]uch a provision may become part of the contract either by express agreement, oral or written, or as a result of an employee's legitimate expectations grounded in an employer's policy statements.”). 
each of these cases, one party kept the goods or labor, so at least a halfhearted argument for consideration can be made; surely that is all that keeps rolling contracts afloat. If in fact the point in time of contract formation is ambiguous, the assent doctrines are actually irrelevant. Even my students quickly note that in the battle of forms, rolling contracts, and employment manual cases courts often hold a party to a contract without any moment of objective assent (and sometimes without any real assent at all, ${ }^{217}$ and when this occurs the law is as akin to unjust enrichment as it is to promise enforcement).

\section{What Consideration Is For, and Contra Assent-Based Takeover} Attempts

Historically, attempts to reduce contract formation analysis to assent and do away with the consideration doctrine have failed. These attempts reflect the reality that assent analysis is actually nothing more than part of consideration. In this subsection, I review some of the most wellknown attempts.

Please keep in mind what consideration is, what it does, and what it is for. As previously stated, consideration exists if the evidence shows that the promise plausibly induced a return promise or performance and that that promise or performance plausibly induced the promise. ${ }^{218}$ I include a longer discussion of consideration's purpose in the companion piece, Consideration and the Formation Defenses, ${ }^{219}$ but a brief exposition is warranted here. Consideration justifies judicial action in response to an allegation of breach of promise. No one advocates enforcing all promises. Consideration gives ground for the state to act.

In our legal system, the first time anyone must pass on the enforceability of a promise is in a default judgment motion, or on a motion to dismiss. The question at that stage is, what is the bare minimum that must be alleged for the promise to be deemed worthy of judicial action, to be worth forcing the promisor to respond? Consideration is that bare minimum. ${ }^{220}$ Sans consideration, a contract

217. See Asmus v. Pac. Bell, 999 P.2d 71, 73 (Cal. 2000) (“An employer may unilaterally terminate a policy that contains a specified condition, if the condition is one of indefinite duration, and the employer effects the change after a reasonable time, on reasonable notice, and without interfering with the employees' vested benefits.”).

218. See supra note 11 and accompanying text.

219. Ricks, supra note 21.

220. Of course, there are technical exceptions, such as the case of so-called promissory estoppel. See, e.g., Ricks, supra note 86, at 112-18. But these cases were handled as consideration cases prior to the invention of promissory estoppel in the first half of the twentieth century. Id.; see also 
action is only that a promise was breached. That a promise is breached tells the judge very little. The circumstances of the promise's making, the reasonableness of it, and whether enforcing it will serve any public purpose are unknown. Leveling the state's enforcement power against a private individual for a private cause is hardly justified by evidence of mere promise and breach.

The existence of consideration changes everything. In its original formulation, consideration requires a benefit to the promisor, detriment to the promisee, or a mutual promise. ${ }^{221}$ If the promisor received a benefit in exchange for the promise, then the benefit provides a reason for the court to require the promisor to answer the complaint; otherwise, the promisor would get something for nothing and be unfairly benefitted. ${ }^{222}$ If the promise induced the promisee to perform some act detrimental to the promisee, then this also provides a reason for the court to require the promisor to respond; otherwise, the promisee would be unfairly charged. ${ }^{223}$

If the promisor and promisee exchange promises, then, if one such promise has been performed, the benefit, detriment, or both, resulting from performance provides sufficient ground alone for enforcement of the other promise. If both promises remain executory (a relatively rare case at the litigation stage), then this also might warrant enforcement. The case has been justified on a number of grounds, including the value of contractual expectations; the social institutions of promising; and the practical need to uphold bargains in which benefit or detriment might well have occurred, as a supplement to cases in which it has. ${ }^{224}$

The judge enforcing the bargain may also infer that, by seeking legal enforcement of the defendant's promise, the plaintiff offers to submit the plaintiff's own promise to legal process. All things being equal, if one of the two promises is enforceable, then both should be. ${ }^{225}$ The plaintiff's willingness to submit therefore implies an offer to provide, on pain of legal penalty, the benefit to the promisor that the plaintiff has promised, or to undertake the detriment of the promisee's performance. The

\footnotetext{
William R. Casto \& Val D. Ricks, “Dear Sister Antillico ...”: The Story of Kirksey v. Kirksey, 94 GEO. L.J. 321, 366-70 (2006). Consideration functions usefully for contract law as described in the following paragraphs, whether or not it includes the cases later handled under promissory estoppel.

221. See Ricks, supra note 86, at 107-12.

222. P.S. ATIYAH, THE RISE AND FALL OF FREEDOM OF CONTRACT passim (1979).

223. Id. at $1-2$.

224. Id. at 3-6.

225. See Ricks, supra note 130, at 516-30 (explaining why mutuality of obligation is logically necessary).
} 
plaintiff's submission of the exchange of promises to the court thereby supports $^{226}$ the court's asking the defendant promisor to respond.

But aside from these specific conclusions, the law can draw several general, justifying conclusions if consideration exists. Most obviously, the consideration provides evidence of assent to the exchange. Proving that the promisor was plausibly induced shows that assent was plausible. Of course, the promisor may not have assented, and the law allows the promisor to prove as affirmative defenses that assent resulted from duress, mistake, or misrepresentation, or that the promise was unconscionable. But at this early stage of litigation, the courts protect promisors by requiring at least an initial showing that consideration existed for a promise, which gives evidence that assent occurred.

Consideration does much more than this. Plausible inducement to an exchange means that each party probably saw the trade as in her best interests, at least ex ante. Folks generally do not exchange unless they are getting more than they give. The plausible exchange in fact suggests that the parties may well have seen the exchange as equivalent, or fair. ${ }^{227}$ Legal support for exchanges in which both parties benefit, or at least which both parties have more or less admitted is equal, is morally less problematic than enforcing a transaction in which one might well be made worse off. In this way, consideration protects the promisor.

All this can be stated another way. The fact of the plausible exchange frees the courts from examining the quality of assent unless the parties seek further review. If the parties have exchanged, then prima facie what they are trading is roughly equivalent, at least in their own eyes, ${ }^{228}$ and they are the people whose interests are most relevant to both the transaction and the litigation. They are also the people who know the deal best. The fact of their exchange thus suggests that the deal is good,

226. Supports but does not fully justify, I propose, because the promisee's concession cannot justify imposing law on the promisor. However, the promisor's implied concession that the bargain is at least an equal trade, see infra text accompanying note 227, adds nearly enough to count as justification. The difficulty is that in no case does the promisor concede specifically to legal process, and it is of course possible that the meaning, objectively and subjectively, of the promisor's conduct does not add up to an assent to legal process even though the promisor has exchanged promises with the promisee-plaintiff.

227. V ARISTOTle, NichOMACHEAN Ethics 5 (W.D. Ross trans.) (350 B.C.E.), available at http://classics.mit.edu/Aristotle/nicomachaen.5.v.html (last visited Dec. 23, 2012) (inferring that "neither would there have been association if there were not exchange, nor exchange if there were not equality" and distinguishing "acting unjustly and being unjustly treated; for the one is to have too much and the other to have too little”).

228. Aristotle recognized this, also: "for neither would there have been association if there were not exchange, nor exchange if there were not equality." Id. 
or at least that the parties have conceded that point with respect to their own interests.

Consideration also provides a public reason for enforcement. Trade is in the public interest, as courts recognized even at the time of consideration's development: "trade and traffic is the life of every commonwealth, and especially of an island."229 The surplus resulting from exchange belongs to the public. ${ }^{230}$ We would say it differently now: that goods and services moving to those who value them more highly than those who trade them creates greater satisfaction for everyone who trades, and thus creates greater wealth. Wealth creation benefits all.

The consideration doctrine thus plays an important role in litigation. When a plaintiff files a contract case, she is required to show promise and breach. But if that were all, the judge would hardly be justified in issuing judgment or requiring the promisor to respond. Consideration is the doctrine that justifies concluding that a prima facie case exists-that justifies a judge in acting in the first instance. Without it, the judge has no idea whether a remedy is justified between the parties or as an act on behalf of the public. With consideration, the judge can at least plausibly say that some minimal judicial action is justified against the party and on behalf of the state; the court is justified in requiring the promisor to answer the complaint. Of course, after the prima facie case is made out, if the promisor wishes the court to look more closely at the bargain, ${ }^{231}$ the court will do so. The defenses to formation examine the exchange in

229. City of London's Case, (1664) 77 Eng. Rep. 658, 663 (K.B.), 8 Co. Rep. 121b, 125 b.

230. In the medieval period in Europe, the idea that surplus was a kind of common public property flowed from the doctrine of a just price. Exchange, according to Aristotle and his scholastic followers, was a matter of commutative justice and was supposed to result in an equal trade. See ARistotle, supra note 227; CRAig MuldREW, The ECONOMY OF OBligation 43-46 (1998). Thus, monopoly, which allowed the seller to demand more than a just price, was a kind of robbery. George O’Brien, EsSAy on Medieval Economic Teaching 68-69 (1920). This kind of thinking appears in case law in the 1500s. In Farmer v. Brook, (1589) 74 Eng. Rep. 132 (K.B.), 1 Leon. 142, a bakery was set up in a manor town in competition with the bakery the lord of the manor had approved. The arguments for the newcomer reveal the public nature of surplus: "[I]t is not reasonable, that such profits be restrained and drawn from the publick good to the private commodity of any person." Id. at 133 . And, "Such a grant was not good to deprive the commonwealth of such a benefit, and to appropriate it to one, which might be profitable to many...." Id. Indeed, as Muldrew points out, the idea of a commonwealth was tied in minds at the time to the common derivation of profit from exchange. MULDREW, supra, at 46. Muldrew cites Thomas Elyot, who argued, in explaining public weal, that "profite is called weale. And it is called a welthy contraye where in all thyng that is profitable. And he is a welthy man that is riche in money and substance.” Id. (quoting ThOMAs Elyot, THE BOKE NAMED tHE GOVERNOUR 1-2 (Henry Herbert Steven Croft ed., 1883) (1531)).

231. See Ricks, supra note 21 (describing how the formation defenses primarily address the showing of consideration rather than the promisor's assent). 
all its facets, including the quality of assent. The consideration doctrine sets up the entire analysis.

What else could the law do? Should we require judges to grant a default judgment on evidence of promise and breach alone? Should we require plaintiffs to show the absence of any defense? Probably half the argument against consideration comes from our obvious silliness of claiming that "a contract exists" if promise and consideration are given. Nothing really exists, at that point, except a legal fiction in a legal mind, and our tendency to think that remedies attach at that point ignores the rest of contract doctrine. It is true that a court could grant a default judgment or refuse a motion to dismiss at that point, but no promisor is going to have to do anything unless she capitulates on the rest of the case or has no better evidence to put up. If she does have better evidence, then, after she presents it, we conclude that there was no legal obligation after all-there was no contract, or, more technically, there was a contract, but it was voidable, and it has been avoided. It is exactly the same thing, either way. ${ }^{232}$ No remedies hang on the difference. If there is a better way to construct contract law, I have not heard of it.

Given the function of the consideration doctrine and its obvious usefulness in the context in which it is employed, it might seem odd that so many attempts have been made to topple it. But attempts are many. None have succeeded. Probably experts in contract doctrine recognize even without articulating it that banishing consideration would leave the law in a lurch, with plaintiffs having to prove things they have no proof of, and that are against their interest, or with the law pegging defendants without having any idea why they promised or whether enforcement would serve anyone's interests but the plaintiff's. Consideration is a much better mechanism to police the initial stages of a contract action.

A history of the failure of attempts to do away with it follows.

\section{a. Pillans v. Van Mierop}

The first prominent attempt to replace consideration with assent occurred before assent was a doctrine of contract law. It happened in the King's Bench in Pillans $v$. Van Mierop. ${ }^{233}$ In this case, White, a

232. The promisor rather than the promisee should logically prove the formation defenses. All the evidence of them is in the hands of the promisor. Forcing a plaintiff to address them would be to have the plaintiff prove a negative. Moreover, promisor-defendants, not promisee-plaintiffs, have the incentive to prove the formation defenses. I address these arguments more fully in Consideration and the Formation Defenses. Ricks, supra note 21.

233. (1765) 97 Eng. Rep. 1035 (K.B.), 3 Burr. 1663. 
merchant, asked for credit from Pillans and Rose, also merchants, to pay a creditor. ${ }^{234}$ Pillans and Rose agreed to extend credit if White would name "a house of rank" in London who would stand behind White. ${ }^{235}$ White named Van Mierop and Hopkins, and Pillans and Rose extended credit to White. ${ }^{236}$ After extending credit, Pillans and Rose wrote to Van Mierop and Hopkins requesting confirmation that Van Mierop and Hopkins would pay the debt of White a month or so later. ${ }^{237}$ Van Mierop and Hopkins confirmed that they would. ${ }^{238}$ But before Van Mierop and Hopkins were called upon to pay White's debt, White "failed," and Van Mierop and Hopkins thereafter refused to pay anything for White. ${ }^{239}$ Pillans and Rose therefore sued. ${ }^{240}$

There was no consideration in the case. ${ }^{241}$ Because Pillans and Rose paid White's creditor before calling upon Van Mierop and Hopkins to cover the credit, that act could not have induced Van Mierop and Hopkins's promise. ${ }^{242}$ This was pointed out to the court. ${ }^{243}$ There was no other possible consideration. ${ }^{244}$ But Lord Mansfield opined that consideration was merely evidence of a promise and was not necessary if the promise was in writing. ${ }^{245}$ Justice Wilmot claimed that consideration was a "guard against rash inconsiderate declarations" and did not apply when the promise was put in writing, which was itself sufficient guard against rash inconsiderateness. ${ }^{246}$ But all four judges agreed that consideration did not apply in this "commercial case[] amongst

\footnotetext{
234. Id. at 1035.

235. Id.

236. Id.

237. Id.

238. Id.

239. Id.

240. Id.

241. Id. at 1038.

242. Id. at 1035.

243. Id. (argument of Davy and Wallace for Van Mierop and Hopkins, citing, inter alia, Hunt v. Bate, (1568) 73 Eng. Rep. 605 (K.B.), 3 Dyer 272a (the leading past consideration case)).

244. Id.

245. Id. at 1038 ("I take it, that the ancient notion about the want of consideration was for the sake of evidence only ....”).

246. Id. at 1038-39. In Wilmot's words, "I can find none of those cases that go upon its being nudum pactum, that are in writing; they are all, upon parol." Id. at 1038. This is a spurious argument, and Wilmot surely knew it. A writing was irrelevant to an assumpsit case on a promise. E.g., Golding’s Case, (1586) 74 Eng. Rep. 367 (K.B.), 2 Leon. 71, 71-72 ("In every action upon the case [upon an assumpsit], there are three things considerable[:] consideration, promise, and breach of promise ...."). It does not follow from a failure to mention an irrelevant fact that it did not exist, nor does it follow that had the fact existed the outcome would have changed.
} 
merchants,"247 for "the convenience of trade and commerce," Wilmot said. ${ }^{248}$

The King's Bench's attempt to throw out consideration for assent was unsuccessful. The House of Lords overruled it in 1778, in Rann v. Hughes. $^{249}$ In Lord Chief Baron Skynner's words, there is no class of contracts besides sealed documents and those with consideration: "If they be merely written... a consideration must be proved." 250 In so stating, Lord Skynner also did away with a second attempt to substitute assent for consideration: the argument that the Statute of Frauds's requirement of a writing made the requirement of consideration unnecessary. In rejecting that argument, Lord Skynner noted that the language of the Statute of Frauds was negative, not positive, and that nothing in it implied that if a writing were present the promise would be enforced. ${ }^{251}$

\section{b. Abolition of the Forms of Action}

I have found no evidence that when the forms of action, including assumpsit, were abolished that lawyers argued that consideration should fall with them, but it would have been a logical time to make the argument. If consideration was merely a formalism attached to a form of action, abolition of the assumpsit form of action presented a grand opportunity to rid the law of consideration doctrine. What I have found, however, suggests that no one even considered the question. When the forms of action were abolished, the consideration doctrine appeared so obviously substantive and necessary that lawyers and judges retained it as a matter of course in contracts cases.

Standard language for explaining which common law doctrines were retained after the forms were abolished went like this:

247. Pillans, 97 Eng. Rep. at 1038-41 (opinions of Lord Mansfield and Justices Wilmot, Yates, and Aston). Three Justices, Wilmot, Yates, and Aston, also claimed there was consideration here. Wilmot and Yates cited Pillans \& Company's failure to take other action against White after Van Mierop promised but before it refused to pay White's bill. Id. at 1039-40. And Aston suggested that Van Mierop, having promised to pay, had the right then to take any of White's assets that they had in their possession, and that this would have been consideration. Id. at 1041. But there was no evidence that Pillans \& Company were induced to inaction by the promise, or that Van Mierop had any of White's property. Id. Both of these rationales were speculations on the facts. The judges obviously wanted to find a binding promise; perhaps their holding that consideration is not required should not surprise.

248. Id. at 1040 .

249. (1778) 101 Eng. Rep. 1014, 1014 n.a. (K.B.), 7 T.R. 350, 350 n.a.

250. Id.

251. Id. 
The old forms and distinctions are abolished, and the plaintiff is required to allege in his complaint "A statement of the facts constituting the cause of action, in ordinary and concise language, without repetition, and in such a manner as to enable a person of common understanding to know what is intended . ...,252

And then the courts went on requiring consideration. ${ }^{253}$

\section{c. Holmes and the First Restatement}

Holmes was no friend to the consideration doctrine. In The Common Law, Holmes purported to trace the doctrine to its roots before concluding that it was something of a formality: "Consideration is a form as much as a seal." 254 It is difficult to know just what Holmes meant by this. He also said, "A consideration may be given and accepted, in fact, solely for the purpose of making a promise binding. ... The root of the whole matter is the relation of reciprocal conventional inducement, each for the other, between consideration and promise.”255 Perhaps as a toast to Holmes, the first Restatement of Contracts reflected this conclusion. It contained an illustration:

A wishes to make a binding promise to his son B to convey to B Blackacre, which is worth $\$ 5000$. Being advised that a gratuitous promise is not binding, A writes to B an offer to sell Blackacre for $\$ 1$. $\mathrm{B}$ accepts. B's promise to pay $\$ 1$ is sufficient consideration. ${ }^{256}$

252. Pierse v. Irvine, 1 Minn. (Terr.) 369 (1857); see also Home Ins. Co. of N.Y. v. Atchison, T. \& S.F.R. Co., 34 P. 281, 284 (Colo. 1893); Terrell v. Frazier, 79 Ind. 473, 475 (1881); Tullis v. Fridley, 9 Minn. 79, 84 (1864); Rogers v. Penniston, 16 Mo. 432, 435 (1852).

253. See, e.g., cases cited supra note 252; see also Kim v. Son, No. G 039818, 2009 WL 597232, at *1 (Cal. Ct. App. Mar. 9, 2009).

254. Holmes, supra note 82, at 215; Krell v. Codman, 28 N.E. 578, 578 (Mass. 1891) (Holmes, J.) ("[C]onsideration is as much a form as a seal ...."). This statement was cited again in Norris $v$. Barbour, 51 S.E.2d 334, 339 (Va. 1949). In Krell and Norris, the statement is supposed to be a legal conclusion drawn from the premise that, absent fraud or unconscionability, the court will not inquire into the amount of the consideration. Krell, 28 N.E. at 578; Norris, 51 S.E.2d at 339. The conclusion does not follow from the premise, however. It only would if the only possible purpose of consideration were to police the bargain. But that is not consideration's only purpose. Patterson's list of other purposes provides examples, and the ones commonly taught to students. See Edwin W. Patterson, An Apology for Consideration, 58 Colum. L. REv. 929, 930 (1958). The doctrine also generally ensures a reason for a remedy, either because one party has given something up or extracted a benefit that needs to be compensated. Further, the doctrine points the law toward a minimal efficiency, given that each party is induced by what the other bargains away, both having independently judged that the transaction is in each party's self-interest. None of these other rationales is new. Each was articulated in the sixteenth century.

255. HOLMES, supra note 82, at 230.

256. RESTATEMENT OF CONTRACTS § 84 cmt. b, illus. 1 (1932). 
But the Restatement (Second) abandoned this position. Consideration, the Restatement's comments require, must be more than "mere pretense." ${ }^{257}$ In other words, the form of it alone was insufficient, and some actual motive must exist at least objectively. The following illustration appears instead:

A desires to make a binding promise to give $\$ 1000$ to his son $\mathrm{B}$. Being advised that a gratuitous promise is not binding, A offers to buy from B for $\$ 1000$ a book worth less than $\$ 1$. B accepts the offer knowing that the purchase of the book is a mere pretense. There is no consideration for A’s promise to pay $\$ 1000$. $^{2}$

In a clear rejection of Holmes's position, the Restatement (Second) recites, "In the typical bargain, the consideration and the promise bear a reciprocal relation of motive or inducement."259 The word "conventional" is omitted. The reporters of the Restatement (Second), I believe, saw that the cases actually apply this rule. ${ }^{260}$ The reporters dealt separately with options and guaranties, which can be seen as special cases. $^{261}$

257. Restatement (SECOND) OF CONTRACTS § $81 \mathrm{cmt}$. b (1981).

258. Id. § $71 \mathrm{cmt}$. b, illus. 5 .

259. Id. cmt. b.

260. The Restatement (Second) gave no source for illustration 5, but equivalent cases exist. See, e.g., O’Neill v. DeLaney, 415 N.E.2d 1260, 1267 (Ill. App. Ct. 1980) (finding a recited and tendered $\$ 10$ to be not bargained for and therefore insufficient).

261. The Restatement (Second) of Contracts deals separately with contracts of guaranty and option contracts, claiming a recital of consideration is sufficient for either. See RESTATEMENT (SECOND) OF CONTRACTS $\S \S 87,88$ (addressing options and guaranties, respectively). Precedent exists for holding options binding on a recited consideration. See RESTATEMENT (SECOND) OF CONTRACTS $\S 87$ reporter's note (listing cases in support of the illustrations). However, a selfdescribed majority of courts continue to hold that a recital is insufficient. See, e.g., Lewis v. Fletcher, 617 P.2d 834, 835-36 (Idaho 1980) (adopting the so-called majority position); 1464-Eight, Ltd. v. Joppich, 154 S.W.3d 101, 110 (Tex. 2004) (describing the Restatement view as the minority position). The Restatement (Second)'s position can be justified for option contracts on the ground that the value of an option is so difficult to determine as to put an evaluation of inducement beyond the normal realm of judicial inquiry. An option is a mere bet on the future price of the underlying property, and that price is speculative. See, e.g., CORBIN ON CONTRACTS, supra note 7, § 127, at 185. A worthless recital might well be inducement for a worthless option, or at least all the inducement that the law needs. The Restatement (Second)'s position with respect to guaranties has been less successful. Courts continue to find actual consideration in guaranty cases, usually that the guaranty induced the creditor to lend money or that the financially interested guarantor has received a benefit as a result. E.g., Chevron Chem. Co. v. Mecham, 536 F. Supp. 1036, 1042 \& n.11 (D. Utah 1982); Superior Wire \& Paper Prods., Ltd. v. Talcott Tool \& Mach., Inc., 441 A.2d 43, 48-49 \& n.8 (Conn. 1981); Martin Printing, Inc. v. Sone, 873 A.2d 232, 238-39 (Conn. Ct. App. 2005); Vogler v. Real Earth U.S. Enters., Inc., 907 S.W.2d 377, 381 (Mo. Ct. App. 1995); Spittler v. Nicola, 479 N.W.2d 803, 807-08 (Neb. 1992); Beltran v. Groos Bank, N.A., 755 S.W.2d 944, 948 (Tex. App. 1988). All of these cases cite Restatement (Second) of Contracts section 88 at the indicated pages but nevertheless find actual consideration. I find section 88 to be widely cited but not widely relied upon. The Restatement (Second) gives a rationale for giving effect to recitals in guaranty contracts 


\section{d. Seals and the Uniform Written Obligations Act}

At common law, sealed documents were binding without consideration in an action of covenant or, for certain types of sealed instruments, in debt sur obligation. ${ }^{262}$ In theory, Slade's Case and similar developments might have allowed many of these same promises to be brought also in assumpsit, ${ }^{263}$ but judges pushed some sealed documents into covenant actions ${ }^{264}$ and continued to allow debt actions on sealed bonds. ${ }^{265}$ Only after statutes abolishing distinctions between the forms of action left only an action in contract ${ }^{266}$ did the effect of a seal become a general question. In the wake of this sort of change, statutes addressing seals popped up across the country. ${ }^{267}$ In general, the statutes modify the effect of the seal, so that it is no longer alone sufficient to make a promise binding, thus mandating that the consideration doctrine apply even to sealed documents. ${ }^{268}$ Later, the UCC overruled the law of seals in nearly every state with respect to sales of goods. ${ }^{269}$ In some states the seal still has independent binding

that is similar to the one given here for options (the creditworthiness of the debtor and the likelihood of default are uncertain), see RESTATEMENT (SECOND) OF CONTRACTS $\S 88 \mathrm{cmt}$. b, and which is about as persuasive. Note that this section would itself not reverse Pillans v. Van Mierop, (1765) 97 Eng. Rep. 1035 (K.B.), 3 Burr. 1663, as the writing in that case does not appear to have included a recited consideration.

262. SimpSON, supra note 141, at 10-13, 88-98.

263. See David Ibbetson, Sixteenth Century Contract Law: Slade's Case in Context, 4 OXFoRD J. LEGAL STUD. 295, 295 (1984).

264. See Codman v. Jenkins, 14 Mass. 93, 93 (1817); Richards v. Killam, 10 Mass. 239, 239 (1813); Garvey v. Dobyns, 8 Mo. 213, 215 (1843); Andrews v. Montgomery, 19 Johns. 162, 162 (N.Y. Sup. Ct. 1821).

265. See State ex rel. Hoke v. Ammons, 10 Ill. (5 Gilm.) 105 (1848); Kime v. Brooks, 31 N.C. (9 Ired) 218 (1848); State ex rel. Smith v. Rector, 29 Tenn. (10 Hum.) 57 (1849) (marriage bond). Assumpsit filled in around the edges. See, e.g., Gilson v. Stewart, 7 Watts 100, 100 (Pa. 1838) (" $[\mathrm{A}] \mathrm{n}$ action of assumpsit will lie upon an express promise to pay 'a debt secured by specialty where' other matters of account between the parties be blended with the settlement of that which arose out of the specialty ....”); Stamper v. Johnson, 3 Tex. 1, 6 (1848) (holding that assumpsit will lie "where a bond or other security ... has been accepted in satisfaction of a simple contract" even if the collateral security taken is of a "higher nature" than the debt).

266. See, e.g., Webster v. Fleming, 52 N.E. 975, 978 (Ill. 1899); Middle States Loan, Building \& Constr. Co. v. Engle, 31 S.E. 921, 922-23 (W. Va. 1898).

267. See RESTATEMENT (SECOND) OF CONTRACTS, ch. 4, topic 3, statutory note (1981).

268. See id. The Restatement (Second)'s note reports that the statutes "make lack of consideration a defense to an action on a contract under seal" (seven states) or "abolish the seal or the distinction between sealed and unsealed contracts" (twenty-four states), id., which probably amounts to the same thing.

269. U.C.C. § 2-203 (2011) ("The law with respect to sealed instruments does not apply to such a contract ...."). 
effect, ${ }^{270}$ but there is considerable divergence in what that means. ${ }^{271}$ Pennsylvania also recognizes the Uniform Written Obligations Act, which holds, "A written release or promise, hereafter made and signed by the person releasing or promising, shall not be invalid or unenforceable for lack of consideration, if the writing also contains an additional express statement, in any form of language, that the signer intends to be legally bound." ${ }^{272}$ But Pennsylvania is now the only jurisdiction in which the Act is law. New Mexico alone has a similar provision. $^{273}$

The history of both the seal and the Uniform Written Obligations Act shows that, as a general matter, our law has gravitated away from making a mere statement of assent sufficient as a binding promise. ${ }^{274}$ In fact, by dropping the seal, the law has largely given the consideration doctrine more authority than it ever had previously. I am aware of numerous particular exceptions to the consideration doctrine. ${ }^{275}$ On balance, however, I believe its authority has expanded rather than contracted in the law during the last two hundred years.

\section{e. Peppercorns}

A note here about peppercorns. The "even a peppercorn is sufficient consideration" mantra has long been a staple of appellate court rhetoric and law school legend.

A story is told of Senior Judge Monroe McKay of the Tenth Circuit U.S. Court of Appeals, how when he was teaching Contracts in the 1970s, he once lay down on the long bench in the moot court room and ruminated about peppercorns for an entire class period. ${ }^{276}$ The peppercorn mantra and such stories give the impression that consideration is a formality because a peppercorn "does not match the

270. See, e.g., Fox v. Christina Square Assocs., C.A. No. 91L-04-6-1-MT, 1994 WL 146023, at *5 (Del. Super. Ct. Apr. 5, 1994); SKF USA, Inc. v. Workers' Comp. Appeals Bd. (Smalls), 714 A.2d 496, 501 (Pa. Commw. Ct. 1998).

271. See, e.g., Joseph M. Perillo, Calamari and Perillo on Contracts § 7.8 (6th ed. 2009).

272. 33 PA. CONS. STAT. § 6 (2011).

273. See N.M. STAT. ANN. § 38-7-2 (2011) ("Every contract in writing hereafter made shall import a consideration in the same manner and as fully as sealed instruments have heretofore done.”).

274. See supra Part III.B.d.

275. I list many of these and refer to others at Ricks, supra note 86, at 142-43 nn.226-32.

276. I have a source for this, but I am not going to give it here. You will have to call me, or ask Judge McKay or one of his former students from the year in which this occurred. 
value received and thus represents nominal payment.,277 If the peppercorn is merely nominal, or in name only, then it has legal effect not because it induces the promise, even objectively, but because it is a formality, like a seal.

In the actual cases, however, the peppercorn language does not have that function at all. Courts reciting the peppercorn mantra actually rule on whether inducement occurred. Some hold explicitly that consideration, even if a peppercorn, must in fact induce the promise, and then they name some promise or performance that obviously is sufficient to induce the promise, before holding that consideration exists. ${ }^{278}$ Other courts, less explicitly, cite the peppercorn language and then find consideration in some promise or performance that is worth far more than a peppercorn and was traded explicitly for, or fairly clearly induced, the promise. ${ }^{279}$ Conversely, when the so-called peppercorn is not

277. King Cnty. v. Taxpayers of King Cnty., 949 P.2d 1260, 1279 n.3 (Wash. 1997) (en banc).

278. See Judwin Props., Inc. v. U.S. Fire Ins. Co., 973 F.2d 432, 435 \& n.3 (5th Cir. 1992) (\$6 million); Pope v. Sav. Bank of Puget Sound, 850 F.2d 1345, 1356 (9th Cir. 1988) (seven acres); Gottlieb v. Tropicana Hotel \& Casino, 109 F. Supp. 2d 324, 329-30 (E.D. Pa. 2000) (participation in a casino game); Fox v. Rodel, Inc., No. 98-531-SLR, 1999 WL 588293, at *8 (D. Del. July 14, 1999) (mem.) (moving expenses); DFP Mfg. Corp. v. Northrop Grumman Corp., No. 97-CV-4494, 1999 WL 33458384, at *5 (E.D.N.Y. Mar. 23, 1999) (mem.) (not to enter into another, similar agreement with anyone else, among other things); White v. Nat'l Football League, 972 F. Supp. 1230, 1237 \& n.5 (D. Minn. 1997) (giving up \$10,000 in 1999 salary and otherwise shifting salary so that the team had salary cap left in 1997); GLS Dev., Inc. v. Wal-Mart Stores, Inc., 944 F. Supp. 1384, 1395 \& n.9 (N.D. Ill. 1996) (that a developer step aside and allow another a certain business opportunity); W \& F Bldg. Maint. Co., Inc. v. United States, 56 Fed. Cl. 62, 66 \& n.14 (Fed. Cl. 2003) (payment of $\$ 43,374$ and mutual settlement of contractual entitlements); Cascade Designs, Inc. v. Comm'r of Internal Revenue, 79 T.C.M. (CCH) 1542, at *10 (T.C. 2000) (a patent, waiver of a contract breach claim, and giving up a claim for unpaid funds); Pruss v. Pruss, 514 N.W.2d 335, 345 (Neb. 1994) (mutual promise to devise property according to terms of a will, explicitly rejecting the idea that a mere formality can serve as consideration); Meyer v. Broekemeier, No. A-02-468, 2003 WL 22076333, at *10 (Neb. Ct. App. Sept. 9, 2003) (indemnifying another party against twenty-five percent of losses incurred from a \$650,000 loan default); First Nat'l Bank of Osceola v. Gabel, No. A-01-968, 2003 WL 21146098, at*8-9 (Neb. Ct. App. May 20, 2003) (foregoing collection of a more than \$200,000 loan and lending another \$35,000); James Neff Kramper Family Farm P'ship v. Dakota Indus. Dev., Inc., 603 N.W.2d 463, 468-69 (Neb. Ct. App. 1999) (paying a lower price if work was not completed on time); Hobin v. Coldwell Banker Residential Affiliates, 744 A.2d 1134, 1138-39 (N.H. 2000) (benefits of a national realtor chain affiliation); Lucky Calendar Co. v. Cohen, 117 A.2d 487, 495-96 (N.J. 1955) (paying additional admission for chance to win a prize); Kings Park Apartments, Ltd. v. Nat’l Union Fire Ins. Co, 101 S.W.3d 525, 532 \& n.3 (Tex. App. 2003) (\$5 million); Richmond Eng'g \& Mfg. Corp. v. Loth, 115 S.E. 774, 787 (Va. 1923) (materials and labor); Lake Holiday Country Club, Inc. v. Love, No. 00-137, 2000 WL 33268347, at*6 (Va. Cir. Ct., July 27, 2000) (country club membership benefits); Washington v. Anderson, CHANCERY NO. 94-58, 1994 WL 1031366, at *2-4 (Va. Cir. Ct. 1994) (repair and remodeling of property).

279. See Reger Dev., LLC v. Nat'l City Bank, 592 F.3d 759, 762 (7th Cir. 2010) (lending at least \$750,000); Delta Health Grp. Inc. v. Royal Surplus Lines Ins. Co., 327 F. App’x 860, 866 (11th Cir. 2009) (forbearance to file a disputed claim); United States v. Miller, 214 F. App’x 630, 631 (8th Cir. 2007) (the government's promise not to seek further charges against a criminal defendant); RLS Assocs., LLC v. United Bank of Kuwait PLC, 380 F.3d 704, 712 (2d Cir. 2004) (obligation to render 
bargained for, it is not consideration. ${ }^{280}$ Plenty of cases recite the
peppercorn language and then find no mutually induced consideration. ${ }^{281}$

assistance in finding a replacement consultant, if requested); Stone Motor Co. v. Gen. Motors Corp., 293 F.3d 456, 461-62 (8th Cir. 2002) (requiring a hearing on the consideration issue notwithstanding a peppercorn recital in the agreement); C-T of Va., Inc. v. Euroshoe Assocs. Ltd. P'ship, 953 F.2d 637, 1992 WL 12307, at *2 (4th Cir. Jan. 29, 1992) (unpublished table decision) (infusion of \$4 million in equity capital); Exch. Nat'l Bank v. Daniels, 768 F.2d 140, 143 (7th Cir. 1985 ) (receipt of $\$ 4.5$ million, re-lent to an entity in which the borrowers owned twenty-five percent); FDIC v. Fedorov, No. 10-11061, 2010 WL 2944569, at *6 (E.D. Mich. July 22, 2010) (disbursement of \$500,000 loan); Vissuet v. Indymac Mortg. Servs., No. 09-CV-2321-IEG (CAB), 2010 WL 1031013, at *4 (S.D. Cal. Mar. 19, 2010) (completion and submission of a loan modification application); Delta Health Grp., Inc. v. Royal Surplus Lines Ins. Co., No. 3:05-CV108/RV/MD, 2008 WL 2509756, at *2 (N.D. Fla. June 19, 2008) (sharing of defense costs), aff'd, 327 F. App’x 860 (11th Cir. 2009); Rosendale v. Mahoney, No. 05 Civ. 01966 (CLB) (LMS), 2008 WL 2061266, at $* 8$ (S.D.N.Y. Mar. 27, 2008) (foregoing other employment); Freightliner of Knoxville, Inc. v. DaimlerChrysler Vans, LLC, 438 F. Supp. 2d 869, 879 (E.D. Tenn. 2006) (a dealer agreement), aff'd in part, rev'd in part, 484 F.3d 865 (6th Cir. 2007); Dalton v. Gen. Motors Corp., No. Civ. 05-727, 2005 WL 2654071, at *6 (D.N.J. Oct. 17, 2005) (payment of \$3.4 million); Martinez v. Bohls Bearing Equip. Co., 361 F. Supp. 2d 608, 630-31 (W.D. Tex. 2005) (settlement of a disputable claim); Gimbel v. Wintroub, No. 02 C 8795, 2004 WL 1470259, at *4 (N.D. Ill. June 30 , 2004) (mem.) (assuring clients and working to protect a contractual relationship); KW Plastics v. U.S. Can Co., No. CIV. A. 99-D-286-N, 99-D-878-N, 2001 WL 135722, at *15 (M.D. Ala. Feb. 2, 2001) (mem.) (good faith negotiation of a supply contract); Gross Mach. Grp. v. M.V. "Alligator Independence,” No. 91 Civ. 0460 (JSM), 1993 WL 77326, at *1 (S.D.N.Y. Mar. 17, 1993) (mem.) (mitigation of a potential claim for attorneys' fees); Leventhal v. New Valley Corp., No. 91 Civ. 4238 (CSH), 1992 WL 15989, at *6 (S.D.N.Y. Jan. 17, 1992) (mem.) (promise not to compete for eight years, inter alia); Don King Prods., Inc. v. Douglas, 742 F. Supp. 741, 761 (S.D.N.Y. 1990) (\$1 million); In re Bowling, No. 01-31346, 2006 WL 4449688, at *4 (Bankr. W.D. Mo. Apr. 4, 2006) (mem.) (giving up a disputable claim); In re Farmland Indus., Inc., 335 B.R. 398, 416 (Bankr. W.D. Mo. 2005) (execution of job duties, despite failure to accomplish major goals); Askinuk Corp. v. Lower Yukon Sch. Dist., 214 P.3d 259, 267-68 (Alaska 2009) (\$1 per year, a promise to renegotiate a long-term rental rate in good faith, and the promise to use the land only for "public school purposes”); Perrymon v. Bullis, No. B207481, 2010 WL 189047, at *1, *7 (Cal. Ct. App. Jan. 21, 2010) (\$200,000); Third Story Music, Inc. v. Waits, 48 Cal. Rptr. 2d 747, 753-54 n.5 (Cal. Ct. App. 1995) (at least $\$ 100,000$ per year for several years); Conn. Nat’l Bank v. Morrissey, No. CV 92-0451236, 1992 WL 228762, at*1 (Conn. Super. Ct. Aug. 28, 1992) (disbursement of $\$ 500,000$ ); Bayshore Royal Co. v. Doran Jason Co. of Tampa, Inc., 480 So. 2d 651, 656-58 (Fla. Dist. Ct. App. 1985) (a promise to guaranty a separate debt); Wadsworth v. Thompson ex rel. Peet, 8 Ill. (3 Gilm.) 423, 429-30 (1846) (use of pledged goods); Messick v. Powell, 236 S.W.2d 897, 899-900 (Ky. 1951) (efforts made by a realtor to sell property); Barry v. Goodrich, 98 Mass. 335, 338-39 (1867) (payment by a third person of part of a debt); Gen. Motors Corp. v. Dep't of Treasury, 644 N.W.2d 734, 739 (Mich. 2002) (a contractual duty to consider complaints in good faith); Shree Shiv Hospitality, Inc. v. Spillane, No. 280361, 2008 WL 4891491, at*3 (Mich. Ct. App. Nov. 13, 2008) (negotiation of a personal property tax matter and increased capacity for a favorable result at a tax auction); Skarina v. Allstate Ins. Co., No. 251191, 2005 WL 900552, at *3 (Mich. Ct. App. Apr. 19, 2005) (\$3,000); Weiner v. McGraw-Hill, Inc., 443 N.E.2d 441, 444-45 (N.Y. 1982) (leaving one employer, rejecting other offers of employment, and going to work for another); Blubaugh v. Merrill, Lynch, Pierce, Fenner \& Smith, Inc., No. CA-6597, 1985 WL 8260, at *3 (Ohio Ct. App. July 8, 1985) (\$85,000 loan); see also, e.g., Williams v. Kan. Dep’t of Soc. \& Rehab. Servs., 899 P.2d 452, 456 (Kan. 1995) (opining that $\$ 10$ could be consideration for a trust but noting that $\$ 1.6$ million was in fact given).

280. See O’Neill v. DeLaney, 415 N.E.2d 1260, 1266 (Ill. App. Ct. 1980) (finding a recited and tendered $\$ 10$ not to be bargained for and therefore insufficient). 
Moreover, a few courts, recognizing that no one would ever bargain for a peppercorn, suggest that a peppercorn, being a mere formality, would be insufficient. ${ }^{282}$ The real meaning of the peppercorn language in contract law is that courts will not second-guess the parties' exchange. This is the way Williston used the phrase, ${ }^{283}$ and Corbin. ${ }^{284}$ Even with that meaning, the mantra is not absolute; there are cases in which courts will examine the adequacy of consideration in a contract: when an equitable remedy is at issue, ${ }^{285}$ when questioning whether a release is knowing and voluntary, ${ }^{286}$ and for unconscionability or fraud, ${ }^{287}$ or perhaps even duress. $^{288}$ Thus, that a peppercorn might be consideration in no way indicates that consideration is a formality.

281. See Gray v. N.Y. Life Ins. Co., 879 F. Supp. 99, 102 (N.D. Ala. 1995); In re Aldersgate Found., Inc., 62 B.R. 621, 623 (Bankr. M.D. Fla. 1986); Kim v. Son, No. G039818, 2009 WL 597232, at *1, *3 (Cal. Ct. App. Mar. 9, 2009) (holding that an "entirely . . gratuitous" promise was not "weightier than a peppercorn”); Steiner v. Thexton, 77 Cal. Rptr. 3d 632, 642-43 (Cal. Ct. App. 2008) (holding that payment of nothing was not enough), rev'd, 48 Cal. 4th 411 (2010) (finding consideration in part performance); Torlai v. Lee, 76 Cal. Rptr. 239, 241-42 (Cal. Ct. App. 1969); Conn. Nat'l Bank v. Giacomi, No. 105860, 1993 WL 392951, at *21-22 (Conn. Super. Ct. Sept. 28, 1993) (mem.) (finding the contract lacking in consideration because it "did not benefit [Ms. DePastino] one iota”), rev'd on other grounds, 659 A.2d 1166 (Conn. 1995); Frankel v. Donovan, 120 A.2d 311, 315-16 (Del. Ch. 1956); Rutherford v. Phillips, No. 2006-CA-000234-MR, 2007 WL 1794902, at*3 (Ky. Ct. App. June 22, 2007); Suske v. Straka, 39 N.W.2d 745, 750 (Minn. 1949); Pruss v. Pruss, 514 N.W.2d 335, 345 (Neb. 1994); Currid v. Meeting House Rest., Inc., 869 A.2d 516, 521 (Pa. Super. Ct. 2005) (holding that the services named in the note were never given).

282. E.g., In re Applied Paging Techs., Inc., 250 B.R. 496, 501 (D.N.J. 2000) (reasoning that bankruptcy trustee's designation of certain assets gave a litigation advantage and thus was "more" than "in the nature of a peppercorn" and would therefore suffice).

283. 1 SAmuel Williston, The LaW OF Contracts § 100 (1924) ("It is sometimes supposed by critics of the doctrine of consideration that the requirement relates to the form rather than the substance of a contract. But this is a misunderstanding. Though a peppercorn may be sufficient consideration for a promise, whether or not it is, depends on whether it was in fact the exchange or at least a requested detriment induced by the promise.").

284. E.g., CORBIN ON CONTRACTS, supra note 7, § 127 ("The gross inadequacy of the consideration, as measured by the opinions of other men, may tend to support the conclusion that the parties did not actually agree upon an exchange, that the 'peppercorn' was not in fact bargained for by the promisor. If it was not bargained for, it was not a consideration, according to the definition that makes agreed bargain the test.") (noting also that when the factor that makes a promise binding is not bargained for, that, too, "must be substantial in character; an inconsequential tomtit will not do").

285. E.g., Haft v. Dart Grp. Corp., Civ. A. No. 13736, 1994 WL 643185, at *2 (Del. Ch. Nov. 14, 1994); Mid-Town Petroleum, Inc. v. Gowen, 611 N.E.2d 1221, 1227 (Ill. App. Ct. 1993).

286. E.g., Chappell v. Butterfield-Odin Sch. Dist. No. 836, 673 F. Supp. 2d 818, 831 (D. Minn. 2009).

287. E.g., Batory v. Sears, Roebuck \& Co., No. 2:02-cv-02026-SWS, 2006 WL 3627124, at *2 (D. Ariz. Dec. 12, 2006); King Cnty. v. Taxpayers of King Cnty., 949 P.2d 1260, 1280 (Wash. 1997) (Sanders, J., dissenting) ("[I]f there is proof of donative intent or a grossly inadequate return, the courts must inquire into the adequacy of consideration ....”).

288. E.g., RESTATEMENT (SECOND) OF CONTRACTS § 176(2) (1981). 
The genesis of the peppercorn language in America is probably English lease cases, transmitted through Blackstone, who wrote,

[A]ll leases for years of land, assignments, and surrenders of those leases ... [-]these very seldom carry the outward appearance of a gift, however freely bestowed; being usually expressed to be made in consideration of blood, or natural affection ... ; and, in case of leases, always reserving a rent, though it be but a peppercorn: any of which considerations will, in the eye of the law, convert the gift, if executed, into a grant; if not executed, into a contract. ${ }^{289}$

This seems like a broad statement and an endorsement of a peppercorn as a formality that will make a contract, but it is not. Leases were almost in a class by themselves in English common law. ${ }^{290}$ Early on, the courts had a broad view of the word "consideration." It was, as Chief Justice Dyer explained in 1574, a "cause or meritorious occasion, requiring a mutual recompense, in fact or in law."291 Dyer listed some transactions requiring a consideration in this broad sense. Please note how he distinguishes contracts from other transactions:

Contracts and bargains have a quid pro quo. Exchanges, annuity for counsel or service, rent services, and tenures for demesnes of lands, as frank-almoin, frankmarriage, homage auncestrel, for warranty and acquittal, ${ }_{292}$ common for cause of vicinage or service, demise of the wife .... ${ }^{292}$

By Dyer's time it was clear that different transactions required different considerations. Dyer is careful to explain that contracts (and he meant by "contract" a transaction that would put one in debt ${ }^{293}$ ) require "quid pro quo." 294 But other kinds of transactions did not. So, though as a matter of general common law, the courts were clear that blood and natural affection were not consideration for a promise in assumpsit, ${ }^{295}$

\footnotetext{
289. 3 BLACKSTONE, supra note $110, * 440$.

290. See generally SIMPSON, supra note 141.

291. Calthorpe’s Case, (1574) 73 Eng. Rep. 756, 759 (K.B.), 3 Dyer, 334b, 336b.

292. Id.

293. In Dyer's time, the word "contract” had not acquired its current meaning, namely, a promise that the law will enforce. In the 1500s, the word was used to refer to transactions that would warrant an action of debt against another. The action of assumpsit, not debt, is the source of our contract doctrine of consideration, though many of the transactions called quid pro quo in Dyer's time would be called consideration today.

294. Id.

295. Bret’s Case, (1600) 78 Eng. Rep. 987, 987 (C.P.), Cro. Eliz. 756 (“[N]atural affection is not sufficient consideration to ground an assumpsit....”); Harford v. Gardiner's Case, (1588) 74 Eng. Rep. 332, 332 (K.B.), 2 Leon. 30 ("Curia, Love is not a consideration, upon which an action can be grounded....”); see generally Ibbetson, supra note 86, at 79-81. The case of a promise made on
} 
such a consideration would suffice for a declaration of a use or trust in land. ${ }^{296}$ Later, when common lawyers claimed that such a declaration of use in land was "a species of contract, or conveyance operating without transmutation of possession" and required a consideration under the common law, ${ }^{297}$ they were quick to say just what was required by way of consideration, and it was not a quid pro quo or what we know today as consideration for contracts. ${ }^{298}$ This warrants some explanation.

The old law held that a bargain and sale, or grant, of land was a transaction requiring consideration if there was any time between the bargain or declaration and the actual conveyance. ${ }^{299}$ This requirement predated the necessity of consideration in assumpsit. ${ }^{300}$ The requirement of consideration for a grant of land was later justified on the ground that a grant was a "species of contract operating under the Statute of Uses, without transmutation of possession," 301 perhaps because transfer of possession was not immediate. Consideration for a grant therefore followed the use cases, not the assumpsit cases. The consideration did not need to be expressed, the money did not need to be paid at the time of the grant, and the sum might be nominal. ${ }^{302}$

A lease was considered a grant of property, ${ }^{303}$ so the consideration rule applicable to it was the rule for uses, or grants, not for promises in assumpsit. So, for instance, when the courts questioned whether a peppercorn as rent could stand as consideration for a lease of land for the

consideration of marriage may have been an exception. See, e.g., Barker v. Halifax, (1600) 78 Eng. Rep. 974, 974 (C.P.), Cro. Eliz. 741 (Walmsley, J.) (“[A]n assumpsit in consideration that you had married my daughter, to give unto you 40l. was good; for the affection and consideration always continues .... .”); see also Ricks, supra note 86, at 110 n.50 (discussing the various reports of Marsh v. Rainsford, (1586) (K.B.)).

296. Sharington v. Strotton, (1565) 75 Eng. Rep. 454 (K.B.), 1 Plowd. 298. Consideration for a grant of use also included money as a recompense, and marriage. SiMPSON, supra note 141, at 36467.

297. Kingsmill v. Sharington, (1582-1584) 76 Eng. Rep. 379, 382 n.E (K.B.), 1 Co. Rep. 175a, 176a n.E.

298. Id. (noting that "marriage, natural love and affection to a legitimate child, brother, nephew, or cousin" would qualify but that the consideration need not be expressed in the declaration).

299. See id. at 381 n.B (stating that a bargain and sale "without transmutation of possession" requires consideration); see also SIMPSON, supra note 141, at 346-48. Some of the cases cited in Note, The Form of Bargain as Consideration in Contracts, 24 Colum. L. REv. 896 (1924), discussed infra Part III.B.2.f., fall into this category.

300. See, e.g., Assaby v. Manners, (1516) 73 Eng. Rep. 520 (Surrey Assize) (Fyneux \& Moore, JJ), 2 Dyer 235a; SiMPSON, supra note 141, at 348-53 (discussing Assaby and other early cases).

301. Kingsmill v. Sharington, 76 Eng. Rep. at 381 n.B.

302. Id.

303. See, e.g., Clarkson v. Hanway, (1623) 24 Eng. Rep. 700 (Ch.), 2 P. WMS. 203. 
use of another, ${ }^{304}$ they looked for precedent in the Sutton's Hospital case, ${ }^{305}$ which held that twelve pence was sufficient consideration for the bargain and sale of land to the use of another. ${ }^{306}$ Twelve pence being clearly nominal, a mere form, the court in the lease case thought a peppercorn no worse. ${ }^{307}$

But the peppercorn's sufficiency for a lease says nothing about what we now call a contract-a promise with consideration. Pressed into service in contract law by someone who did not understand the common law's distinction between a promise in assumpsit and a grant of property in a lease, the peppercorn language misleadingly suggests that consideration is a formality when it is not. Repeated year after year by contracts teachers who also do not know the difference, the peppercorn mantra continues to mislead law students who, studying this subject in their first semester, can be forgiven for confusion over it. These students later become judges and, repeating the mantra but following the law, leave in the cases the same confusing rhetoric they were forced to hear as students.

\section{f. Consideration as a Formality_Largely a Doctrinal Misunderstanding}

I have already mentioned the first Restatement's position that consideration was a formality, and the Restatement (Second)'s reversal. In fact, I have been looking for many years for a case in which a court approved truly nominal consideration-consideration in name only and not in substance. Instead, what I have found in cases where courts find consideration is that the parties may well have seen something about the arrangement that pleased them, either by providing them or someone they care about a benefit or by preventing a loss, and with only a little imagination I can see it. Of course, proving that no formalism was ever accepted by the courts outside of lease cases, ${ }^{308}$ options, ${ }^{309}$ and perhaps a few other well-known and easily justifiable anomalies would be

\footnotetext{
304. Barker v. Keate, (1677) 86 Eng. Rep. 868 (K.B.), 1 Mod. 262.

305. (1610) 77 Eng. Rep. 960, 975 (K.B.), 10 Co. Rep. 23a, 34a.

306. Barker, 86 Eng. Rep. at 869.

307. Id. The court also considered in this case that possession had not been given to the lessee. Id. In fact, the transaction was arranged to carry out a common recovery, id., a sham litigation procedure meant to destroy the effect of a fee tail and give the current possessor a fee simple. Given the circumstances, requiring more than a peppercorn would have lessened the effectiveness of the common recovery, with which the court appeared sympathetic. See id.

308. See supra Part III.B.2.e.

309. See supra note 261 and accompanying text.
} 
impossible, as proving a negative always is, but I hope I may ask that readers of these cases also exercise a little more creativity. Real consideration is not that hard to find.

For instance, a Columbia Law Review note from 1924 tried to demonstrate The Form of Bargain as Consideration in Contracts. ${ }^{310}$ The Note illustrates several classic misunderstandings of the doctrine of consideration, and its conclusion relies on these misunderstandings.

\section{i. Misreading the Cases}

The Note's first exhibit is Thomas $v$. Thomas. ${ }^{311}$ The Note reports, "There the executors, in compliance with the [oral] dying wishes of the testator, promised to convey a house to the latter's wife, it devolving upon her to pay one pound yearly as part of the ground rent, and to keep the house in repair." ${ }^{\text {"12 }}$ This much is in the case itself. But then the Note spares nothing to characterize the case as the court's approval of mere form:

The executors made the promise out of deference to the deceased's wishes, and intended the conveyance to be a gratuity. The requirement of one pound rental and keeping the house in repair was not the price of the promise-rather it was descriptive of the conditions under which the gift was to be made. But the arrangement was put in the form of a bargain, which, with the requirement of rental indicated a conscious intent to assume legal obligations. Despite the gratuitous character of the transaction, the court, finding the possibility of bargain-equivalents in the payment of rental and the undertaking to repair, enforced the promise to convey the house.

Well, none of this is in the case's facts. This is the writer's characterization of the facts; in fact, it is defense counsel's version of the facts. ${ }^{314}$ It hardly counts as proving your point to recite the arguments of counsel that the court rejected. Chief Justice Denman called defense counsel's argument "a great deal of ingenuity, and a little willful blindness to the actual terms of the instrument itself."

The opposite tale is more plausible: In fact, the executors had a duty to execute the will of the testator, including with respect to the house.

\footnotetext{
310. See Note, supra note 299.

311. (1842) 114 Eng. Rep. 330 (K.B.), 2 Q.B. 851.

312. See Note, supra note 299 , at 898.

313. Id.

314. Thomas, 114 Eng. Rep. at 332-33.

315. Id. at 333 .
} 
The executors were convinced this oral will-making episode took place, ${ }^{316}$ but even if they were not, there was a will contest to avoid. The oral will mandated that they give the widow either possession of the house or $100 .^{317}$ In taking possession of the house, the widow gave up her alternate right to the $100 l$, thus freeing the estate of the liability. Furthermore, the case does not say who owns the house, but rent was to be paid to the executors. ${ }^{318}$ Alas, the Thomases may have had only possession of this house, not ownership. In that case, the repair obligation may well have satisfied the executors' duty under another lease to repair, or have been valuable in its own right as keeping the property occupied and valuable during a period in which no other tenant could be found. Finally, in British common law, rent may in fact be a nominal amount, as a conveyance or grant is not governed by the same law as a promise, as noted in the last section. ${ }^{319}$ The court's thinking was along all of these lines. ${ }^{320}$ The upshot is that this case has nothing to do with proving the form of bargain as consideration for a promise in contract law.

Those arguing for consideration as a form should remember that it is not actual inducement that the courts are after, though they are happier when they feel it present, but only the objective manifestation of inducement. The doctrine requires only an inference of inducement based on the parties' manifestations. In those cases in which inference plays a larger role than direct proof of inducement, even when the inference is likely, the opposite inference can also be drawn, and the plausibility of the opposite inference sometimes tricks writers into asserting that the courts relied merely on a formality. That is what happened to Thomas in the Note.

This is also the Note's take on the apparently nominal consideration that supports some real estate options and promises of guaranty. ${ }^{321}$ What looks like nominal consideration here is in fact probably impossible to judge. An option may or may not be worth anything, depending on what the parties think the value of the real estate will be when the option is exercised. In fact, if the optionor is certain the value of the property will decline, any sum will induce the optionor's promise to hold the offer open. Because that is true, courts are particularly ill-equipped to judge

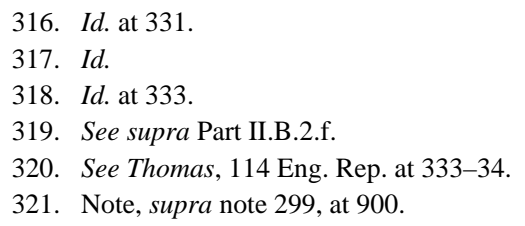


bargains in this circumstance, especially by inference, and some have in fact dispensed with the requirement and allowed a recital to serve. ${ }^{322}$ The application of the consideration doctrine in this special case is no reflection on it generally, however.

A guaranty is similar. Whether the guaranty is necessary depends on the likelihood of the debtor's default, and how valuable a guaranty is depends on the debtor's integrity and net worth, as well as the guarantor's net worth. But courts examining these facts would come close to judging the adequacy of consideration. Leaving the value of the guaranty to the creditor's judgment practically requires a finding that any consideration will do. I must add, though, that many courts require consideration for a guaranty and find it in the giving of the loan. ${ }^{323}$

For another group of cases cited in the Note, ${ }^{324}$ the Note frankly admits that it honestly does not know which inference to draw: "In all these cases it may well be that an actual bargain was both intended and performed."325 Exactly.

\section{ii. Different Policy $=$ Doctrinal Anomaly}

Courts also sometimes make or dispense with the inference of inducement on separate policy grounds. They did this, for instance, when enforcing donative promises under the doctrine of consideration. ${ }^{326}$ In these cases, while everyone knew that no true bargain existed, they also knew that the promises were salutary, and they used contract law as a doctrinal method of reaching the right result. The cases are a doctrinal anomaly, but an old, well-established one, and there is no evidence that anyone was misled by them, at least not in the three hundred years before Williston.

So, when the text of the Note proposes charitable subscriptions as cases of consideration as formality, it first has to bend the cases to fit that

322. See, e.g., Smith v. Wheeler, 210 S.E.2d 702, 704 (Ga. 1974).

323. E.g., Super 8 Worldwide, Inc. v. Am. Lodging Partners, Inc., No. 08-CV-4514, 2011 WL 248447, at *6 (N.D. Ill. Jan. 25, 2011); Pac. W. Bank v. Stull, No. E050551, 2011 WL 664017, at *10 (Cal. Ct. App. Feb. 24, 2011); TD Bank, N.A. v. M.J. Holdings, LLC, No. CV106003386, 2011 WL 1030160, at *2 (Conn. Super. Ct. Feb. 17, 2011); Smith v. Bethlehem Sand \& Gravel Co., LLC, 342 S.W.3d 288, 294 (Ky. Ct. App. 2011) ("[W]here the consideration between the principal obligor and the creditor has passed and become executed before the contract of the guarantor is made and the guaranty was part of the inducement to the creation of the original debt, such consideration is sufficient to the contract of the guarantor ....").

324. Note, supra note 299 , at $900-01$.

325. Id. at 901.

326. See Casto \& Ricks, supra note 220, at 366-70; Ricks, supra note 86, at 104-12. 
description. It does this in a footnote. ${ }^{327}$ The footnote first asserts that charitable subscription cases are sometimes reasoned as mutual promise cases, even though there is no bargained-for mutual promise. ${ }^{328}$ The mutual promise is fictional. This argument actually does not support the formality thesis. That a court relies on a fictional mutual promise, or one that is not bargained for, does not mean that consideration is a formality. A fiction and a formality are not the same thing. Any number of other good reasons may exist to assert a fiction, all of which reflect substantive reasons in favor of enforcement, and none of which equal bargain, and none of which is a formality.

The footnote then asserts that the charitable subscription cases are based on "quasi-estoppel," but this is called "detriment consideration.",329 Of course, this assertion in the footnote disproves the statement in the Note's text that these cases hold consideration a formality. ${ }^{330}$ The quite substantive doctrine of "quasi-estoppel" is no more a formality than is consideration. It is not a bargain, but that something is not a bargain does not mean that it is merely formal, and the footnote proves the point.

The same analysis holds, but conversely, for another line of cases the Note employs. Part payment of a liquidated debt is not consideration for the promise to settle the debt, but, the Note relates, only the slightest extra something thrown in will make the promise enforceable: a cow, several bushels of corn, payment before maturity, the giving of additional security, payment to a third person, etc. ${ }^{331}$ The Note claims all these are but formalities. The Note is misreading the cases. These are substantive bargains: each such item is plausibly a fresh cause. Moreover, the law has very substantive reasons to overrule Foakes v. Beer, ${ }^{332}$ as anyone who has read the excellent arguments of counsel in that case knows. Fictionalizing the consideration requirement in such cases, even assuming it occurs, reflects those excellent arguments, and that explains this very substantive line of cases enforcing such agreements. None of this means the consideration requirement is a formality.

The court in fact might do the same thing by inferring a bargain in a Foakes v. Beer-type case. My favorite case along these lines is Reynolds $v$. Pinhowe. ${ }^{333}$ In Reynolds, the defendant had a judgment of five pounds

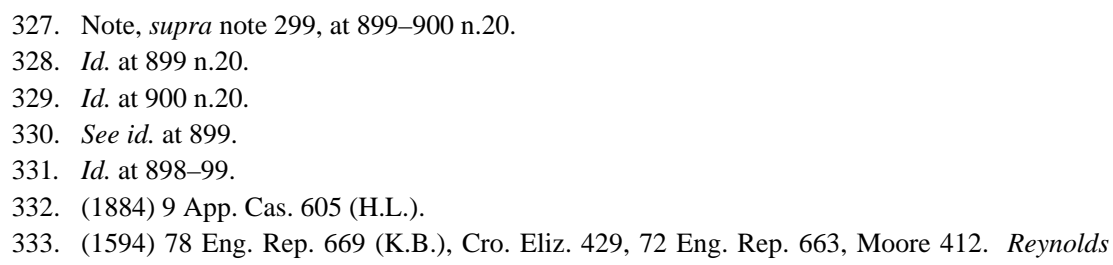


against the plaintiff. ${ }^{334}$ The plaintiff paid the defendant four pounds, and the defendant promised to acknowledge satisfaction of the judgment. ${ }^{335}$ Now under Foakes, this promise is unenforceable, but the court inferred consideration: "it is a benefit unto him to have it without suit or charge." ${ }^{336}$ Well, not having to pursue collection procedures was a benefit Foakes completely discounted (Foakes itself is a collection action), probably as part of the debtor's prior obligation. But the Reynolds court considered it a benefit. The report does not mention that avoiding collection procedures was the actual motivation of the creditor, but nearly every creditor would sacrifice part of the debt to avoid them, and the Reynolds court merely recognized this. Consideration analysis provided a public reason for this promise, one that today many courts might follow but for Foakes.

\section{iii. A Formal Analysis Despite a Real Bargain}

The Note finally mentions cases in which courts engaged in a stilted analysis of the recitations in a contract when a real bargain probably existed on the side or when there was some other reason to enforce the promise. $^{337}$ This seems like quibbling. Moreover, it is entirely possible that, given the varied instruction on consideration doctrine by courts, commentators, and teachers of contract law, occasionally judges can be forgiven for errant analyses.

Other authorities that look for consideration as a form make the same mistakes. I am not contending that no employment of consideration as a pure formality has ever occurred. Even if I have the doctrine correct here, the huge volume of contract cases, the number of lawyers and judges involved, the variety of ways in which contract law is taught, and the variety of legal situations - all but a few of which go unreportedvirtually ensure that somewhere some legal actor will always think of consideration as a formality. To say, however, that "consideration is as much a form as a seal" is incorrect. It is not. Consideration is the requirement of a substantive reason for enforcing a promise and the specification of one kind of reason as sufficient. It is not a strong

\footnotetext{
predates Pinnel's Case, (1602) 77 Eng. Rep. 237 (C.P.), 5 Co. Rep. 117a, the precedent followed in Foakes.

334. Reynolds, 78 Eng. Rep. at 669.

335. Id.

336. Id.

337. See Note, supra note 299, at 901-02.
} 
requirement; a plausible substantive reason is sufficient. But consideration is not a formality, and most of the arguments I have read that try to show that it is a formality are deficient for the reasons given here.

\section{SUMMARY AND RECOMMENDATIONS}

\section{A. Summary}

Because assent can exist without consideration but consideration, when it exists, necessarily implies assent, of these two parts of contract formation consideration is the one both necessary and fundamental. So long as the law requires consideration, an additional assent requirement is superfluous.

The logic of assent's subordinate position has pressed limitations on the so-called doctrine of assent. Even when our contract law purports to require assent, it hedges the requirement with limits on the kind of assent that qualifies. Assent doctrine requires that each party put up either a promise or performance, and what each party does must have reference to what the other party does, and assent must be given by one who knows or has reason to know that the other party may take it as a bargain. These limitations essentially force assent to look more or less like consideration. For why we should duplicate the consideration doctrine with a separate doctrine called assent, the law provides no clear answer.

Fortunately, the historical record of contract law's development reveals why a doctrine of assent arose. The doctrine arose from a need in certain cases to say when a promise became binding (meaning here, prima facie actionable). A promise becomes binding when consideration is given for it. At that moment, the promise becomes prima facie actionable. Historically, this question was complicated by time rules, specifically the rule that one of two mutual promises could not serve as consideration for the other unless both promises occurred at the same time. This time rule obviated the need to find objective mutual inducement in some difficult cases. But it also omitted from contract law's reach agreements formed over time-for example, by post or when the last party to commit took time to decide. When courts realized the common need for these kinds of agreement to be enforceable, they bent or fictionalized (or perhaps discarded) the time rule. In place of it, courts began asking when an exchange was offered and accepted, holding that a contract formed at the time of acceptance.

This change occurred rather late in contract law's history. Our contract law functioned well without any assent analysis from its genesis 
in the 1500s until 1818. The law worked well largely because the consideration doctrine-which not only implicitly required assent but also ensured that a ground for actionability of a promise existed, and often looked at the reason for making the promise-justified legal intervention in otherwise private parties' affairs. When it arose, the problem of when a contract formed was handled by asking when a promise occurred and when another party acceded to it by providing consideration. Doctrines that justified nonenforcement of a prima facie actionable promise-duress, fraud, mistake, and unconscionabilitydeveloped during this period and are fully justified not merely by reference to the assent implicit in the consideration requirement but only by the full requirement of a promise exchanged for another promise or a performance. ${ }^{338}$ The advent of assent analysis in contract law therefore changed little. Assent doctrine only concerned when consideration came to exist.

For many years after courts began talking in terms of assent, courts understood that they were asking through the assent analysis when consideration existed. But over time, the focus of contract law commentary shifted. The consideration doctrine, which was not fully described and elucidated until the early twentieth century, was considered difficult to understand and perhaps primitive. Moreover, the rhetoric of that age favored individualism and freedom. In the heyday of what is often called "classical contract" law, the assent concept came to be favored over consideration as a trigger for contractual liability, and while consideration was not discarded, some tried to reduce it to a formality and predicted its demise. In that context, assent was taken as an element of contract formation. It is from that context that the Restatements and our better-known treatises were organized.

But consideration did not die, attempts to kill it notwithstanding. It is still with us, and it is not a formality. That means that a promise, to be legally enforceable, must, unless some other way is provided, be given for a consideration. Consideration subsumes assent, meaning that consideration cannot be found unless assent has occurred. Because this is true and consideration is required, assent is always already required. A separate analysis of whether assent occurred is superfluous. Assent is already part of the consideration analysis. Occam's razor, the principle of parsimony, and the need to give a clear explanation of the law require that assent be dropped as a separate element.

338. See Ricks, supra note 21. 


\section{B. Recommendations}

\section{A New List}

Presently the most common lists of elements for a contract include assent. ${ }^{339}$ For instance, the Mississippi Supreme Court recently affirmed, "In order for a contract to be valid, six elements must be present: (1) two or more contracting parties, (2) consideration, (3) an agreement that is sufficiently definite, (4) parties with legal capacity to make a contract, (5) mutual assent, and (6) no legal prohibition precluding contract formation.”340 This very common list will have to change. Item (5) should be expunged. It is already included in (2).

Other changes should also be made to the list. First, contract law is not relevant at all unless some party has made a commitment to do something. This is a promise. ${ }^{341}$ Promise is omitted from the list, quite mysteriously. Number (3) on the list requires "agreement," but a person can agree to a barter, or to a statement of facts. No commitment is required by this list, so the list cannot be the list of elements of a contract. Promise, the primary element, is omitted.

Second, item (1) is superfluous. One party cannot exchange with itself, so (2) already mandates a second party. One party will be the party who makes a promise, and some other party must promise or perform the other part of the exchange. That is two parties.

Third, a contract does not require "parties" with legal capacity to make a contract. This item perhaps itself deserves a paper, but promisees need not have contractual capacity if they do not need to make a binding promise. Because consideration need not be a promise, in many cases only one party to the contract, the promisor, needs the capacity to make a binding promise. A minor who performs the consideration binds the nonminor party to the contract. The promisee who has been adjudicated mentally incompetent but whose guardian hands over the consideration ${ }^{342}$ binds the promisor. ${ }^{343}$ That is probably why the Restatement (Second)

339. See supra note 1.

340. Estate of Davis v. O'Neill, 42 So. 3d 520, 527 (Miss. 2010) (internal quotation marks omitted). This list may be Murray's. See MurRay, supra note 1, § 28.

341. "A contract is a promise or set of promises ...." RESTATEMENT (SECOND) OF CONTRACTS $\S 1$ (1981).

342. Id. § 71(4) ("The performance or return promise ... may be given by the promisee or by some other person.”).

343. Joon, of Benny \& Joon (1993), was schizophrenic and an artist. If Joon painted a painting for a collector who knew of her illness, which the collector accepted and displayed, would Joon be able to collect? If she is just mentally incompetent, her contracts are voidable in her favor. 
limits its direct statements on this issue to holding that the incompetent person has no legal capacity "to incur contractual duties," 344 which is beyond dispute. But only the promisor must have capacity. An optionor who becomes incompetent or even dies after granting the option is bound to it when the option is exercised, ${ }^{345}$ even though that optionor is the promisor. The list exaggerates the need for capacity.

With these changes in place, the list looks much different: A contract requires (1) a promise (2) that is sufficiently definite (3) by a party with capacity, (4) consideration, and (5) no legal prohibition. What of assent, then? Consistent with its subordinate role, assent should be described as part of the consideration requirement. A contract will form when all of the elements exist, but typically the triggering mechanism will be when either promise or consideration occurs, whichever is last, those being the two elements that require legal action by the parties.

The following language added to the italicized rule above captures this and states assent's role in the law of contract formation: $A$ consideration is a promise or performance given in exchange for the promise. A contract forms when each element has occurred. Typically, one party makes an offer, and the other accepts. An offer must either make a promise and propose a consideration, or provide consideration and propose a promise. An acceptance must either provide the proposed consideration or make the proposed promise. Assuming the other elements are met, upon acceptance, a contract forms.

With this list in place of the other, the rest of the doctrines largely still retain the sense they have in the law. Whether we are discussing promise and consideration or mutual assent, the requirement is an objective manifestation. A promise and consideration can be objectively manifest, as can assent. In fact, assent that is in fact a promise and consideration is what the law requires to be manifest now. Changing the list and subordinating assent to part of the consideration and promise analysis merely puts the assent requirement as it is actually applied and as the logic of the doctrine requires it.

I suspect some will resist this change in the list with the feeling that, once we drop assent as fundamental, we are no longer talking about

RESTATEMENT (SECOND) OF CONTRACTS $\S 15$. In that case she should be able to collect. If her brother, who in the movie acts as her guardian, had been appointed legal guardian of her person and property, should she (or he as her guardian) then have no contractual rights, even though she has performed?

344. Id. § 13.

345. Id. §§ 37, $48 \mathrm{cmt}$. d. 
contract. A contract is an agreement, they think. That is the common usage. Or the contract is a document that people have signed. I have encountered this feeling in my students. But that is generally because they have never considered what the law is asked to do with these doctrines.

The law is never asked to enforce an agreement. More specifically, the law is asked to enforce a promise-some commitment a person has made for the future. Whether that person has to perform that promise or remedy its breach is the issue in each contract case. Only one promise at a time is at issue, and only one breach. That is how the doctrines, which were developed in response to the requirement of a promise and consideration, are constructed. Now it may be that both parties have promised and breached, but still the law does not consider enforcing an agreement as such. Instead, the law takes each promise one at a time and applies the formation doctrines and then the formation defenses. A formation defense in favor of one party does not settle the enforceability of the other party's promise, which still must be given with consideration. The fact of our doctrine is that it becomes clear only when one forgets about agreements and focuses on the enforceability of one promise at a time and the remedy for its breach.

\section{Teaching Order}

I almost smile when I look back on the struggles the law has had in teaching what is an offer. The test of Lefkowitz ${ }^{346}$ is notoriously vague, and Leonard ${ }^{347}$ is no better (which is partly why Leonard is so long). Both serve in casebooks as an introduction to a list of examples rather than an explanation of what is legally required. ${ }^{348}$ In the Restatement and all the major treatises and hornbooks, the same problem is caused by addressing assent first. ${ }^{349}$ But if assent is nothing more than discerning when a promise and consideration have occurred, then the teaching order ought to be switched. If consideration is taught first, then the offer is easy to discern.

346. Lefkowitz v. Great Minneapolis Surplus Store, 86 N.W.2d 689 (Minn. 1957).

347. Leonard v. PepsiCo, 88 F. Supp. 2d 116, 122-30 (S.D.N.Y. 1999), aff'd, 210 F.3d 88 (2d Cir. 2000).

348. See, e.g., BLUM, supra note 3, at 100.

349. RESTATEMENT (SECOND) OF CONTRACTS §§ 18-23, 71-81; see, e.g., WiLliston, supra note 6 (acceptance and assent are published in volume two and consideration is published in volume three). 
What is an offer? If the class has already studied promise and consideration, this should be no problem. In fact, the offer is the proposing of a bargain, either the making of a promise and the proposing of a consideration, or the provision of consideration and the proposing of a promise, with the invitation that the offeree accept by either providing the proposed consideration or making the proposed promise; assenting to the offer does just that. Acceptance is also determined by this test. The other offer rules regarding termination of the power of acceptance, notice, ${ }^{350}$ and so on, can be taught as before. The acceptance rules, including the mirror image rule and acceptance by conduct, can also be taught as before.

This order of teaching has benefits also for topics that technically fit within offer and acceptance but only oddly so. For instance, issues of whether one accepts by making a return promise or by performance ${ }^{351}$ depend on the content of the proposed exchange. Knowing this makes the prevailing rule (where no manner of acceptance is specified, a promise is acceptable ${ }^{352}$ ) more sensible. What intent must accompany an act for that act to be acceptance (an issue that arises in reward cases, for instance $^{353}$ ) is a near cousin with a line of consideration cases that find implied inducement when the promisee knew about the promise and knew that the promise would benefit her. ${ }^{354}$ Acceptance-by-silence-plussome-sort-of-action cases ${ }^{355}$ also make more sense; the proposed bargain often needs no more than dominion of the goods by the offeree. ${ }^{356}$ And finally, battle of the forms law $^{357}$ can be explained as a search for the parties' bargain in fact and also as the imposition by law of default terms for things the parties have not actually bargained for, a rationale that ties UCC section 2-207 to both the rest of Article Two code and the other

350. The rule of Carlill v. Carbolic Smoke Ball Co., (1893) 1 Q.B. 256 (Eng.), that in a unilateral contract notice of acceptance at the time of notice of performance is sufficient, seems like common sense when one realizes that the bargain proposed is the promise of the reward in exchange for the purchase and use of the product. Studying previously the content of such reward exchanges removes the oddity from the case. Trades of promises for actions have been enforceable as such for 450 years.

351. See, e.g., Gleeson v. Frahm, 320 N.W.2d 95, 97 (Neb. 1982); RESTATEMENT (SECOND) OF CONTRACTS $\S 32 \mathrm{cmt}$. b.

352. RESTATEMENT (SECOND) OF CONTRACTS $\S 32$.

353. E.g., Simmons v. United States, 308 F.2d 160, 164-65 (4th Cir. 1962).

354. See Di Cicco v. Schweizer, 117 N.E. 807, 811 (N.Y. 1917).

355. See, e.g., Lee v. Sheller Globe Corp., 661 F. Supp. 6, 7 (S.D. Miss. 1986); Louisville Tin \& Stove Co. v. Lay, 65 S.W.2d 1002, 1003 (Ky. 1933); Austin v. Burge, 137 S.W. 618, 619 (Mo. Ct. App. 1911).

356. See Louisville Tin \& Stove Co., 65 S.E. 2d at 1003; Austin, 137 S.W. at 619.

357. U.C.C. § 2-207 (2011). 
formation doctrines. But these methods of teaching these assent-related doctrines only work well if the class has already studied consideration.

When I discussed this paper with colleagues before publication, one asked me whether any cases would be decided differently if the changes I am proposing were to be made. My answer to that is both "no" and "yes." I am not here advocating for an actual change in the results of any case. There is no set of facts upon which I am suggesting the law has ruled wrongly. I am not a social engineer here, at least not in a direct sense. But I believe strongly that if students are taught the law as it actually fits together, they will understand contract law much better than they would otherwise. Having understood it as students, they will make far fewer mistakes as judges. They will have a much better chance at creating useful and fair contract law. The economy will be governed not by ad hoc application of doctrines about which judges are confused, but deliberately; actual understanding of the doctrine is a precondition of wise decisions. And lawyers who understand will argue far more persuasively as advocates. They will have the confidence to change the law when necessary. And they will be able to explain the law much more ably to those who rely on contract law, the clients we serve.

\section{Better Theory}

Finally, I expect better theory from this understanding of the law. Theorists have long ignored consideration, waiting for it to die. If they understood that, all this time, it and the reasonableness it ensures actually form a bedrock of promise enforcement, they would address it more carefully. 